\title{
Green Synthesis of Pd Nanoparticles for Sustainable and Environmentally Benign Processes
}

\author{
Oriana Piermatti
}

Citation: Piermatti, O. Green Synthesis of Pd Nanoparticles for Sustainable and Environmentally Benign Processes. Catalysts 2021, 11, 1258. https://doi.org/10.3390/ catal11111258

Academic Editor: Nicola Della Ca

Received: 30 September 2021

Accepted: 18 October 2021

Published: 20 October 202

Publisher's Note: MDPI stays neutral with regard to jurisdictional claims in published maps and institutional affiliations.

Copyright: (C) 2021 by the author Licensee MDPI, Basel, Switzerland. This article is an open access article distributed under the terms and conditions of the Creative Commons Attribution (CC BY) license (https:// creativecommons.org/licenses/by/ $4.0 /)$.
Dipartimento di Chimica, Biologia e Biotecnologie, Università degli Studi di Perugia, Via Elce di Sotto 8 , 06123 Perugia, Italy; oriana.piermatti@unipg.it

\begin{abstract}
Among transition metal nanoparticles, palladium nanoparticles (PdNPs) are recognized for their high catalytic activity in a wide range of organic transformations that are of academic and industrial importance. The increased interest in environmental issues has led to the development of various green approaches for the preparation of efficient, low-cost and environmentally sustainable Pd-nanocatalysts. Environmentally friendly solvents, non-toxic reducing reagents, biodegradable capping and stabilizing agents and energy-efficient synthetic methods are the main aspects that have been taken into account for the production of Pd nanoparticles in a green approach. This review provides an overview of the fundamental approaches used for the green synthesis of PdNPs and their catalytic application in sustainable processes as cross-coupling reactions and reductions with particular attention afforded to the recovery and reuse of the palladium nanocatalyst, from 2015 to the present.
\end{abstract}

Keywords: Pd nanoparticles; green synthesis; bioreduction; biopolymers; green supports; heterogeneous catalysis; C-C coupling reactions; reduction reactions

\section{Introduction}

Currently, growing environmental concern requires the development of green and environmentally sustainable strategies for the preparation of metal nanoparticles [1,2].

Metal nanoparticles (MNPs) with a high surface to volume ratio, serve an important role in a wide range of disciplinary field such as catalysis, bio-diagnostics, medicine, drug-delivery, pharmacology, energy production and environmental remediation.

Among the various MNPs, due to their unique electronic and chemical properties, palladium nanoparticles (PdNPs) have attracted major attention for their high efficiency as heterogeneous nanocatalysts for various organic transformations such as C-C coupling reactions, hydrogenation of alkenes and alkynes, oxidation reactions, reduction of nitroarenes and degradation of dyes [3-7]. Pd nanocatalysts not only enhance the synthetic performance of a chemical process but allows the use of milder conditions and the development of a greener chemistry. Thus, clean and non-toxic synthetic routes for Pd nanoparticles production are highly desirable for the development of environmentally friendly processes.

The catalytic and biological activity of PdNPs are closely related both in their shape and size and in the nature of the dispersing/capping agent. Moreover, the synthetic procedure for PdNPs preparation plays a significative role in defining unique properties such as their chemical, physical, optical and electronic properties.

To date, many synthetic approaches have been explored for the preparation of $\mathrm{Pd}$ nanoparticles, including different physical, chemical, electrochemical and biological methods (Figure 1) [8,9].

Physical methods often require the use of sophisticated equipment but it is possible to finely control the size and the dispersion of metal nanoparticles on the surface of the support. Moreover, both ultrasonic and microwave radiation have been widely used as alternative energy source for the synthesis of PdNPs in solution. The electrodeposition 
process allows high purity and the precise control of size of the metal nanoparticles simply by monitoring the key parameters of the applied current, the voltage and time. Chemical procedures are simplest and they are the most widely used methods for Pd nanoparticle's synthesis in solution. The reduction of $\mathrm{Pd}(\mathrm{II})$ metal ions to $\mathrm{Pd}(0)$ requires a reducing agent in the presence of a suitable capping or dispersing agent to nucleate $\operatorname{Pd}(0)$ with a welldefined size and shape. The chemical methods require the use of an over-stoichiometric amount of a strong reducing agent or an excessive amounts of solvents. Thus, biological methods that use biogenic materials as a reducing and capping or a dispersing agent are emerging as a new green procedure for the production of Pd nanoparticles in an aqueous medium [9-15].

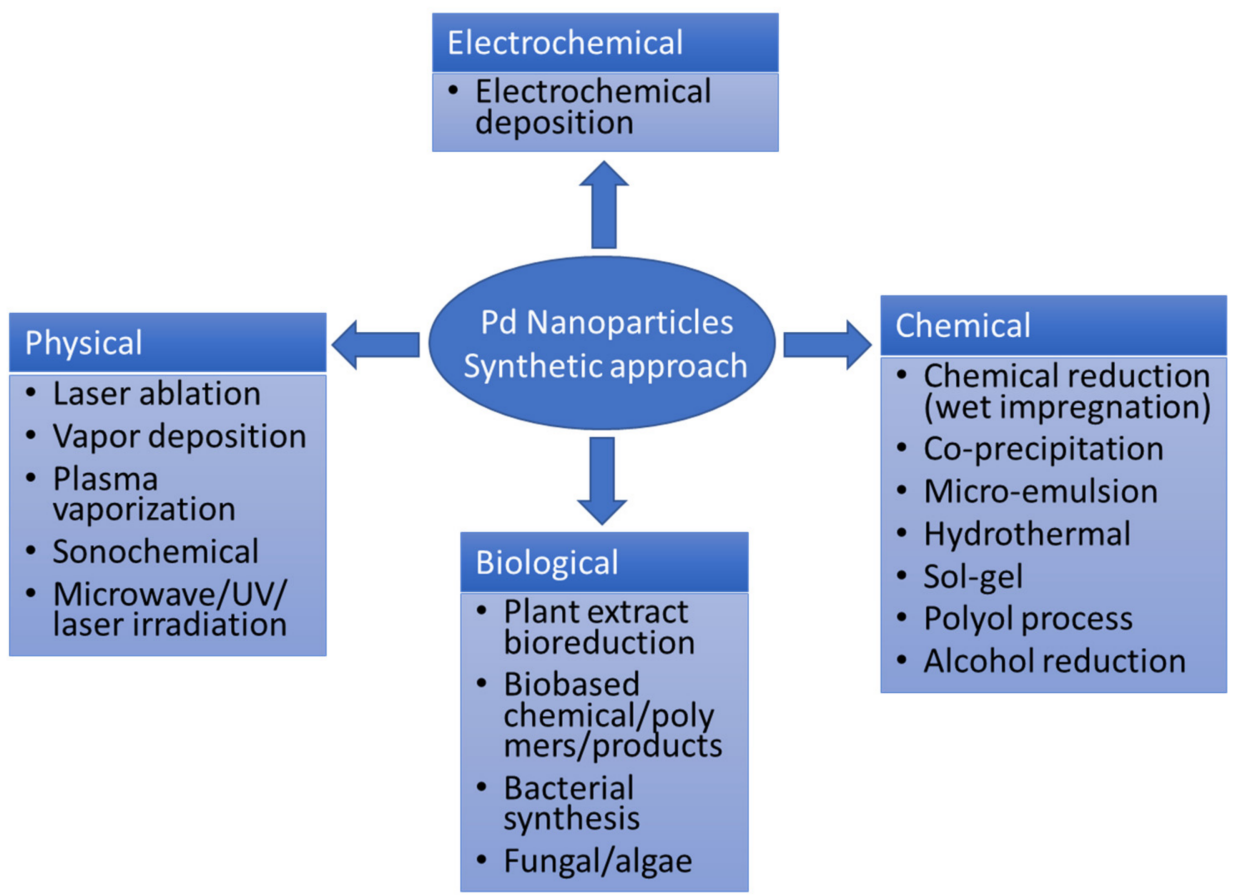

Figure 1. Physical, chemical and biological synthetic approach to Pd nanoparticles preparation.

As is known, Pd catalysts play a key role in the chemical industry production of complex molecules such as fine chemicals and pharmaceuticals, and in recent year, much attention has been afforded in designing efficient, low-cost and environmentally sustainable PdNPs nanocatalysts via green methods.

Indeed, the implementation of sustainable chemical processes requires the use of a catalyst that is safe, economical, simple to prepare, easily recoverable and reusable with minimal Pd leaching. This approach affects sustainability in different ways: (i) the catalyst can be recovered and reused and this reduces the amount of waste generated and the amounts of resources used (ii) The leaching in the product is limited and this reduces the product purification processes, which is very important in pharmaceutical preparations, because a rigid regulation regarding the maximum amount of metal permissible exists.

The use of solvent-free conditions or alternative green solvents to classical organic solvents such as water, solvent derived from lignocellulosic biomass valorization (carbonates, esters, amides, alcohols) or from industrial waste (PolarClean) in combination with continuous flow technologies and an activation with microwave or ultrasound radiation, contributes to the achievement of low-cost and environmentally sustainable processes [16-26].

This review provides an overview of the different approaches used for the green production of PdNPs from 2015 to the present. Also, the synthetic applications of such synthesized Pd nanocatalyst in fundamental organic processes, mainly C-C coupling (such as Suzuki-Miyaura, Sonogashira, Heck-Mizoroki) and reductions, in environmentally 
safer reaction conditions will be discussed (Figure 2). Particular attention will be paid to the recovery and reuse of the Pd nanocatalysts and to Pd leaching in solution.

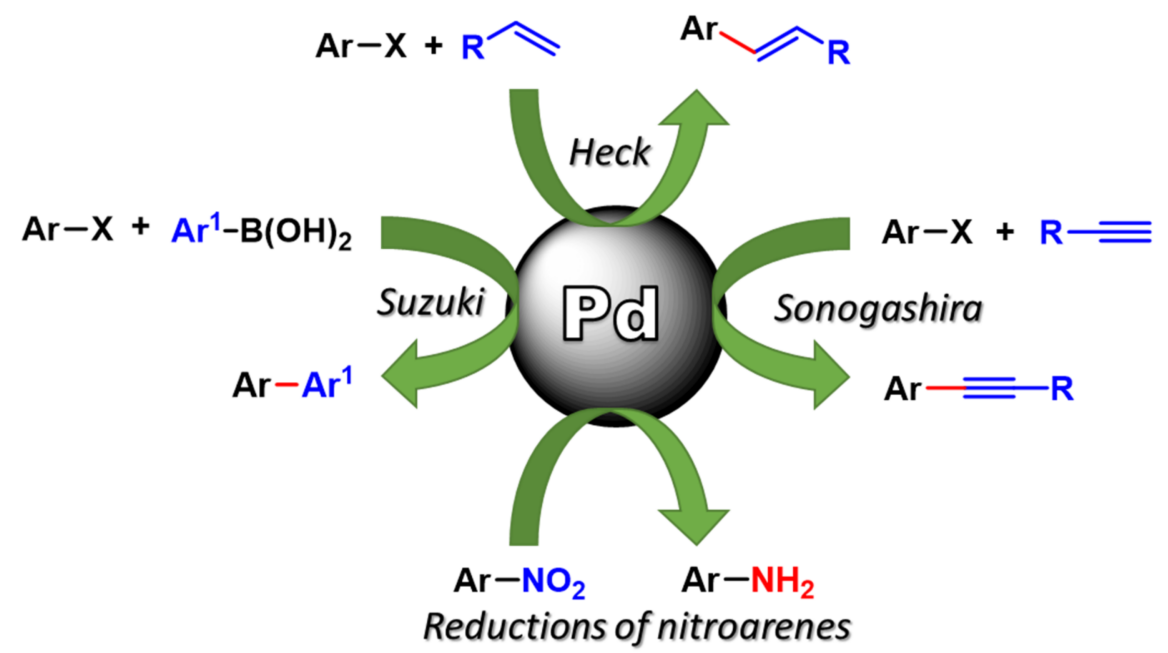

Figure 2. Synthetic application for PdNPs nanocatalysts.

From a mechanistic point of view, both homogeneous catalysis in which PdNPs serve as a reservoir of active molecular species (release and catch mechanism), and a heterogeneous pathway in which PdNPs exhibit a surface reactivity, or a combination of both processes can be operative. Of course, the nanoparticle size, the nature of the reducing and stabilizing agent, nature of support, the reaction conditions such as temperature, reaction medium and the nature of reagents contribute toward determining the catalytic mechanism.

For the purpose of elucidating the mechanistic pathways, several studies such as kinetics, a hot filtration test, polymer test, mercury test, and catalyst characterization after catalysis were used.

In almost all the examples presented in this review, a heterogeneous catalysis is reported by the authors, and the few exceptions will be discussed.

\section{PdNPs Preparation by Pd(II) Chemical Reduction}

When considering the green synthesis of palladium nanoparticles by chemical reduction of the corresponding $\mathrm{Pd}(\mathrm{II})$ ion salt, there are three key factor to be considered: (i) the rection medium, (ii) the reducing agent and (iii) the stabilizer or dispersing agent.

The majority of synthetic procedures employ the use of highly reactive reducing agents such as sodium borohydride $\left(\mathrm{NaBH}_{4}\right)$, hydrazine $\left(\mathrm{N}_{2} \mathrm{H}_{4}\right)$, formaldehyde and hydrogen $\left(\mathrm{H}_{2}\right)$, a capping agent such as surfactants, synthetic polymers, and an organic solvent.

For green perspectives, the use of environmentally friendly solvents, non-toxic chemicals and biodegradable capping agents are high desirable [27].

A number of analytical techniques were used to confirm the formation of palladium nanoparticles as well as to establish their size, morphology, surface characteristics and oxidation state. Commonly, PdNPs are characterized by ultraviolet-visible spectroscopy (UVVis), Fourier-transform infrared spectroscopy (FT-IR), X-ray diffraction (XRD), scanning electron microscopy (SEM), transmission electron microscopy (TEM), energy-dispersive $\mathrm{X}$-ray spectroscopy (EDX), and thermal gravimetric analysis (TGA).

\subsection{Natural Reductant}

Currently, the use of benign chemicals is one of the crucial issues to consider when designing a green process. Natural antioxidants such as vitamin $C$, monosaccharides and gallic acid have been used as reducing agents for the green synthesis of metal nanoparticles [28]. Some recent examples on the preparation of Pd nanoparticles are provided below.

In 2019, the use of sodium ascorbate as an environmental and biocompatible reductant, conjugated with bio-compatible phosphonic acid stabilizers was reported by 
Guénin and co-workers [29]. The described methodology leads to the formation of highly stable and dispersible Pd-NPs in aqueous media by using microwave heating. The effect of the stabilizers and the variation of the $\mathrm{pH}$ of the stabilizer solution was studied. In basic conditions, monodispersed small sized PdNPs (from $2 \mathrm{~nm}$ to $7 \mathrm{~nm}$ depending on the stabilizer) were obtained. The great versatility of these nanocatalysts has been evaluated for different important reactions such as $\mathrm{C}-\mathrm{C}$ coupling, reduction and cyclization in an aqueous or aqueous/ethanolic (1:1) medium without any additives and display a high efficiency. A very low Pd loading $(0.002 \mathrm{~mol} \%)$ was used for the complete conversion in the Suzuki-Miyaura reactions of aryl iodide with tolyl boronic acid under microwave irradiation at $80^{\circ} \mathrm{C}$ for $30 \mathrm{~min}$ (TOF $130,000 \mathrm{~h}^{-1}$ ).

Bora and co-workers report a facile methodology for the Suzuki-Miyaura coupling in water by using gallic acid, a natural and abundant phytochemical, as a reducing agent and stabilizing agent to produce in-situ mono-dispersed palladium nanoparticles from $\mathrm{PdCl}_{2}$ [30]. A TEM image of the reaction mixture after the completion of the Suzuki reaction indicated the formation of uniform palladium nanoparticles with an overage dimension of $15 \mathrm{~nm}$. After the extraction of the biphenyl product, the recovered catalytic solution was reused for up to three cycles, following the addition of fresh reactants, with only a slight decrease in activity $(99 \rightarrow 91 \%$ yield). There was no observed leaching of $\mathrm{Pd}$ in the product.

In the same year, Camp and co-workers described the use of glucose for the in-situ formation and stabilization of Pd nanoparticles during Heck, Sonogashira and Suzuki crosscoupling reactions in an aqueous medium in the presence of $\mathrm{PdCl}_{2}$ [31]. The recyclability of the aqueous in-situ formed palladium nanoparticles was evaluated in the Heck reaction of iodobenzene with methyl acrylate. A drop-off in reactivity was observed after the 4th cycle $(97 \rightarrow 61 \%$ yield). The decrease in yield was most likely caused by the low level of sugar residue on the surface of the nanoparticles which lead to an increased aggregation and deactivation of the PdNPs.

\subsection{Plant Extracts}

Natural reducing agents from leaves, flowers, fruits, seeds, back and roots plant extract have been widely used for the green synthesis of Pd nanoparticles [32]. The phytochemical components contained in the extracts such as polyphenol, flavonoids, terpenoids, polyols, glycosides, vitamins, amino acids and carboxylic, act as alternative reducing and capping agents. Indeed, these compounds possess hydroxyl and carboxylic groups that can coordinate and reduce the $\mathrm{Pd}(\mathrm{II})$ metal ion to zero-valent state. The chelate $\mathrm{Pd}(0)$ atoms act as nucleation centers leading to a growth process which forms stabilized PdNPs. (Figure 3).

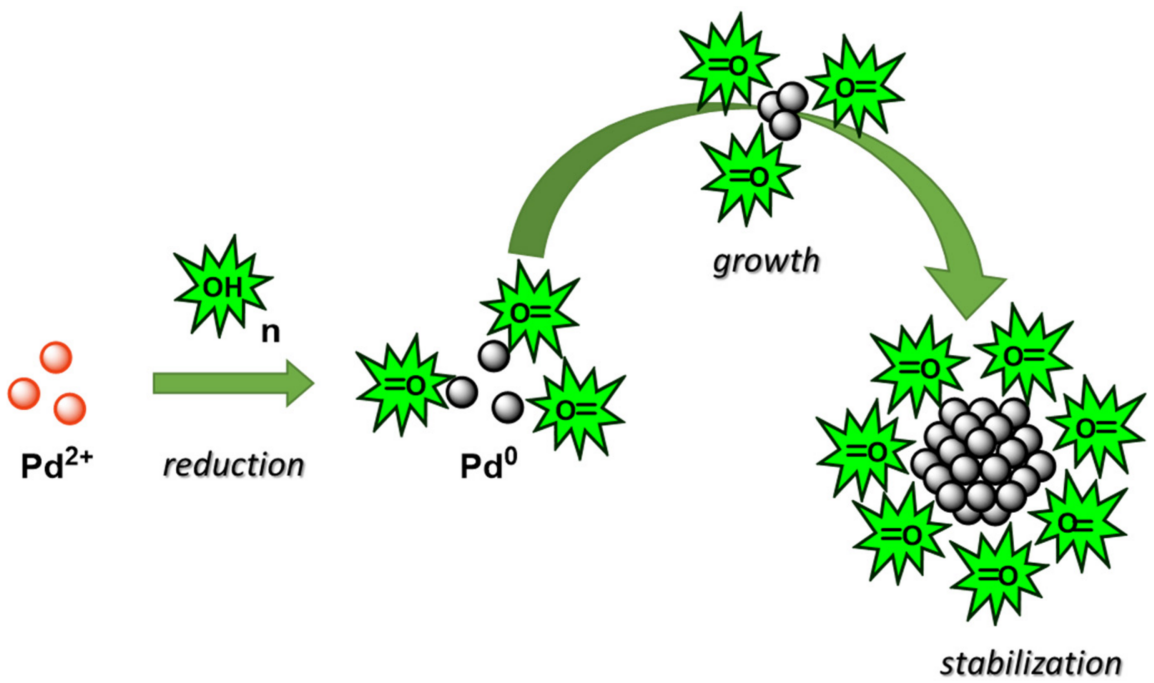

Figure 3. PdNPs formation by plant extract reduction and stabilization. 
The concentration of the phytochemical in the extracts changes considerably according to the type of plant extract, and this affects the size and shape of metal nanoparticles and consequently affects its chemical and biological activity. Also, other reaction conditions such as reaction time, temperature and $\mathrm{pH}$ have a considerable impact on the size, morphology and stability of synthesized nanoparticles [10].

Moreover, recent papers revealed that Pd nanoparticles obtained through a plantmediated biogenic approach are less toxic and biocompatible [33] and present important activity as an antioxidant, anticancer, antimicrobial and antiproliferative $[9,10,12,34-44]$, and can be used for environmental remediation [45].

Table 1. Green synthesis of PdNPs by various part of plant extracts and their applications.

\begin{tabular}{|c|c|c|c|c|}
\hline Plant & Part Used & Size/Shape of PdNPs & Catalytic Application & Reference \\
\hline Areca Nut & husk & $16 \mathrm{~nm}$, spherical & $\begin{array}{l}\text { Synthesis of } \alpha \text {-cheto imide } \\
\text { Heck coupling reaction } \\
\text { Denitrogenative coupling rection }\end{array}$ & [46] \\
\hline Coleus amboinicus & leaf & $20 \mathrm{~nm}$, spherical & Suzuki coupling reaction & [47] \\
\hline Rosmarinus officinalis & leaf & $15-90 \mathrm{~nm}$, semi-spherical & Heck coupling reaction & [48] \\
\hline Gymnema sylvestre & leaf & 10-20 nm, quasi-spherical & Reduction of Cr(IV) & [49] \\
\hline Boswellia sarrata & leaf & $6 \mathrm{~nm}$, spherical & Suzuki and Heck coupling reaction & [50] \\
\hline Punica granatum & peel & $22 \pm 5 \mathrm{~nm}$, spherical & Reduction of 4-nitrophenol & {$[51]$} \\
\hline White tea & leaf & $11 \pm 2 \mathrm{~nm}$, spherical & C-O cross coupling reaction & [52] \\
\hline $\begin{array}{l}\text { Ocimum sanctum } \\
\text { Aloe vera }\end{array}$ & leaf & $\begin{array}{l}4-5 \mathrm{~nm} \text {, spherical } \\
4-5 \mathrm{~nm} \text {, spherical }\end{array}$ & $\begin{array}{l}\text { Sonogashira coupling reaction } \\
\text { Suzuki coupling reaction }\end{array}$ & [53] \\
\hline Acacia concinna & pods & $20 \mathrm{~nm}$, spherical & Suzuki coupling reaction & {$[54]$} \\
\hline Lantana camara & flower & $\begin{array}{l}\text { from } 4.6 \text { to } 6.3 \mathrm{~nm}, \\
\text { spherical }\end{array}$ & Suzuki coupling reaction & [55] \\
\hline Lagerstroemia speciosa & leaf & $136 \mathrm{~nm}$, aggregates & Reduction of 4-nitophenol and dyes & [56] \\
\hline Terminalia arjuna & bark & $\begin{array}{l}8.94 \mathrm{~nm} \text {, most spherical, } \\
\text { few hexagonal, triangular }\end{array}$ & Suzuki and Heck coupling reaction & [57] \\
\hline Papaya & peel & $2.4 \mathrm{~nm}$, spherical & Suzuki and Sonogashira coupling & [58] \\
\hline Piper nigrum & fruit & $2-7 \mathrm{~nm}$, spherical & Hiyama coupling reaction & [59] \\
\hline Thymbra Spicata & leaf & 5-7 nm, spherical & $\begin{array}{l}\text { Suzuki coupling reaction } \\
\text { Reduction of 4-nitrophenol }\end{array}$ & {$[60]$} \\
\hline Glycyrrhiza glabra & root and branches & $3-6 \mathrm{~nm}$, not reported & Suzuki coupling reaction & [61] \\
\hline Artemisia abrotanum & leaf & $20 \mathrm{~nm}$, spherical & Suzuki coupling reaction & [62] \\
\hline $\begin{array}{l}\text { Camelia sinensis } \\
\text { (black tea) }\end{array}$ & leaf & $7 \mathrm{~nm}$, spherical & $\begin{array}{l}\text { Suzuki coupling reaction } \\
\text { Reduction of 4-nitrophenol }\end{array}$ & [63] \\
\hline Pimpinella tirupatiensis & leaf & $12 \mathrm{~nm}$, spherical & Reduction of dyes & {$[64]$} \\
\hline Origanum vulgare L. & leaf & $2.2 \mathrm{~nm}$, spherical & Oxidation of alcohols. & [65] \\
\hline Chrysophyllum cainito & leaf & $\begin{array}{l}\text { 25-50 nm, flower-like } \\
\text { aggregates }\end{array}$ & $\begin{array}{l}\text { Suzuki and Heck coupling reaction } \\
\text { Reduction of nitrophenols }\end{array}$ & {$[66]$} \\
\hline Fenugreek tea & seeds & 20-50 nm, spherical & $\begin{array}{l}\text { Suzuki coupling reaction } \\
\text { Reduction of 4-nitrophenol }\end{array}$ & [67] \\
\hline Salvadora persica L. & root & 2.2-15 nm, spherical & Suzuki coupling reaction & [68] \\
\hline Sapindus mukorossi & seed & $3.6 \mathrm{~nm}$, spherical & Suzuki coupling reaction & [69] \\
\hline Hibiscus sabdariffa $\mathrm{L}$. & flower & $5-8 \mathrm{~nm}$, spherical & Suzuki coupling reaction & [70] \\
\hline Green tea & leaf & 7-10 nm, spherical & $\begin{array}{l}\text { Suzuki coupling reaction } \\
\text { Reduction of nitroarenes }\end{array}$ & [71] \\
\hline Poplar & leaf & $4.2 \mathrm{~nm}$, spherical & Suzuki coupling reaction & {$[72]$} \\
\hline Euphorbia granulate & leaf & 25-35 nm, spherical & Suzuki coupling reaction & [73] \\
\hline Rosa canina & fruit & $10 \pm 3 \mathrm{~nm}$, spherical & Suzuki coupling reaction & [74] \\
\hline $\begin{array}{l}\text { Hippophae rhamnoides } \\
\text { Linn }\end{array}$ & leaf & $5 \pm 2.5 \mathrm{~nm}$, spherical & Suzuki coupling reaction & [75] \\
\hline Stachys lavandulifolia & leaf & 5-7 nm, spherical & Suzuki coupling reaction & [76] \\
\hline Piper longum & fruit & 5-40, spherical & Sonogashira coupling & [77] \\
\hline Euphorbia thymifolia L. & leaf & 20-30 nm, spherical & Hiyama and Stille coupling reaction & [78] \\
\hline Water melon & rind of fruit & $96 \mathrm{~nm}$, spherical & Suzuki coupling reaction & [79] \\
\hline
\end{tabular}


Recent examples of the green synthesis of Pd nanoparticles mediated by plant extracts and their application as catalysts are shown in the Table 1. Some examples are briefly described below.

The Pd nanoparticles were prepared in an aqueous medium by mixing the plant aqueous extract with an aqueous solution of $\mathrm{Pd}(\mathrm{II})$ ion precursor such as $\mathrm{PdCl}_{2}, \mathrm{Pd}(\mathrm{OAc})_{2}$, $\mathrm{Na}_{2} \mathrm{PdCl}_{4}$, and the mixture was stirred in thermal conditions across a wide range of temperatures (r.t. $-100{ }^{\circ} \mathrm{C}$ ) and reaction times (few minutes- $48 \mathrm{~h}$ ) or under ultrasonic vibration [47] or microwave irradiation [49]. The average size of the $\mathrm{Pd}$ nanoparticles varies considerably with the nature of the extract and the reaction conditions used for the preparation.

The Pd nanocatalysts have been employed in various organic transformations such as C-C coupling, reduction and oxidation reactions usually performed in a sustainable green solvent such as water or a water/ethanol mixture. The catalysts have been recovered and reused for several cycles and in general, a slight decrease of catalytic activity was observed. However, in some cases, the catalytic performances decline drastically at the second/third cycle and PdNPs aggregation was observed [65,72].

High catalytic activities were observed by Hekmati and co-workers in the Suzuki reaction in a water/ethanol solution catalyzed by PdNPs@Thymbra spicata [60] and by Veisi and co-workers in the Suzuki reaction in solely water catalyzed by PdNPs@Rosa canina [74] or by PdNPs@Stakys lavandulifolia [76]. The catalysts were recovered and reused for 7-8 cycles without a loss of catalytic activity. Moreover, a hot-filtration test and the very low Pd leaching in solution suggested that the prepared catalysts were stable and a heterogeneous mechanism has been proposed by the authors.

In 2020, the use of PEG-400 as an alternative green solvent for the Suzuki reaction catalyzed by PdNPs@CA (Coleus amboinicus) under ultrasound irradiation, was reported by Kim and co-workers [47]. An excellent reaction yield was obtained in only $30 \mathrm{~min}$ and the catalyst was recovered and efficiently reused for seven cycles without a loss of activity (98 $\rightarrow 95 \%$ yield).

In 2018, Patil and co-workers reported the use of PdNPs@Piper nigrum in the Hiyama reaction in ethylene glycol as a green solvent. The catalyst was recovered and reused for 11 cycles with only a slight decrease of catalytic performance ( $98 \rightarrow 88 \%$ yield) [59].

An efficient catalyst for the reduction of 4-nitrophenol in water was reported in 2017 by Veisi. An aqueous extract of natural black tea leaves was used as a reducing and stabilizing agent for the synthesis of Pd nanoparticles. The as-prepared Pd@B.tea NPs catalyst was used for 9 cycles without a loss of its catalytic activity [63].

Moreover, plant extracts have been used to form and stabilize PdNPs on the surface of solid supports such as $\mathrm{Fe}_{3} \mathrm{O}_{4}$ magnetic nanoparticles, graphite, organic polymers, silica, metal oxides and natural clays to increase the stability and the recyclability of as-prepared Pd nanocomposites.

Indeed, the presence of residual phytochemicals on the surface of a solid support not only acts as a reducing agent but also facilitates the homogeneous distribution of PdNPs on the surface of the support and enhances the aqueous dispersibility of the resulting Pd-composite.

Recent examples on the immobilization of PdNPs on the surface of solid supports stabilized by a plant extract, and their catalytic applications, are reported in Table 2. Some examples are briefly described below.

Among the various solid supports used for the immobilization of palladium nanoparticles, magnetic nanoparticles (MNPs) have emerged as ideal supports because of their high surface area, their stability, low cost and good biocompatibility. Moreover, MNPs are simply and efficiently removed from reaction mixtures with an external magnetic field, reducing the metal contamination of products and simplifying recovery and reuse, all of which are fundamental aspects for a green approach $[5,99]$. 
Table 2. Plant extract as reducing and stabilizing agent for PdNPs production on the surface of solid supports.

\begin{tabular}{|c|c|c|c|c|}
\hline Support & Plant Extract & Size/Shape of PdNPs & Catalytic Application & Reference \\
\hline \multirow{4}{*}{$\mathrm{Fe}_{3} \mathrm{O}_{4}$ magnetic NPs } & $\begin{array}{l}\text { Fritillaria imperialis flower } \\
\text { extract }\end{array}$ & 20-30 nm, quasi-spherical & Reduction nitroarenes & [80] \\
\hline & Strawberry fruit extract & $<20 \mathrm{~nm}$, quasi-spherical & Suzuki coupling reaction & [81] \\
\hline & Tannic acid & 5-25 nm, quasi-spherical & Suzuki coupling reaction & [82] \\
\hline & $\begin{array}{c}\text { Euphorbia condylocarpa M. bieb } \\
\text { root extract }\end{array}$ & $39 \mathrm{~nm}$, not reported & $\begin{array}{l}\text { Reduction of 4-nitrophenol } \\
\text { Suzuki and Sonogashira } \\
\text { coupling reaction }\end{array}$ & [83] \\
\hline \multirow{5}{*}{ Graphene Oxide (GO) } & Coleus amboinicus leaf extract & 20-30 nm, spherical & Reduction of 4-nitrophenol & [84] \\
\hline & Artemisia abrotanum leaf extract & Not reported & Suzuki coupling reaction & [85] \\
\hline & Piper nigrum leaf extract & 6-20 nm, not reported & Oxidation of alcohols & [86] \\
\hline & Thymbra spicata leaf extract & $12-15 \mathrm{~nm}$, cubic & Cyanation of Arylaldehydes & [87] \\
\hline & Pulicaria glutinosa leaf extract & $\begin{array}{l}15-18 \mathrm{~nm} \text {, triangle } \\
7-8 \mathrm{~nm} \text {, spherical }\end{array}$ & Suzuki coupling reaction & [88] \\
\hline $\mathrm{GO}-\mathrm{F}_{3} \mathrm{O}_{4}$ & Origanum vulgare leaf extract & $10-40 \mathrm{~nm}$, not reported & $\begin{array}{l}\text { Suzuki coupling reaction } \\
\text { Reduction of 4-nitrophenol }\end{array}$ & [89] \\
\hline \multirow[t]{2}{*}{$\mathrm{TiO}_{2}$} & $\begin{array}{c}\text { Green tea leaf extract or Coffee } \\
\text { powder extract }\end{array}$ & $10 \mathrm{~nm}$, not reported & $\begin{array}{l}\text { Azo-Dyes degradation } \\
\text { Hydrogen production }\end{array}$ & [90] \\
\hline & Myrtus communis L. leaf extract & $17-25 \mathrm{~nm}$, spherical & $\begin{array}{l}\text { Suzuki coupling reaction } \\
\text { Heck coupling reaction }\end{array}$ & [91] \\
\hline $\mathrm{CuO}$ & Theobroma cacao L. seeds extract & $40 \mathrm{~nm}$, not reported & (DMF) & [92] \\
\hline Zeolite & $\begin{array}{c}\text { Anacardium Occidentale shell } \\
\text { extract }\end{array}$ & 1-2 nm, spherical & $\begin{array}{l}\text { Reduction of 4-nitrophenol } \\
\text { Suzuki coupling reaction }\end{array}$ & [93] \\
\hline $\mathrm{LDH}$ & Pine needle extract & $1.75 \mathrm{~nm}$, not reported & Suzuki coupling reaction & [94] \\
\hline MMT-K10 & $\begin{array}{c}\text { Ocimum } \\
\text { sanctum leaf extract }\end{array}$ & 3-6 nm, not reported & Oxidation of alcohols & [95] \\
\hline MMT & $\begin{array}{l}\text { Ocimum } \\
\text { sanctum leaf extract }\end{array}$ & $10-80 \mathrm{~nm}$, not reported & $\begin{array}{c}\text { Hydrodechlorination of } \\
\text { 4-chlorophenol } \\
\text { Hydroxylation }\end{array}$ & [96] \\
\hline Egg shell & Barberry fruit extract & $<20 \mathrm{~nm}$, spherical & $\begin{array}{c}\text { phenylboronic acid } \\
\text { Reduction of 4-nitrophenol } \\
\text { and dyes }\end{array}$ & [97] \\
\hline PEG & Colocasia esculenta leaf extract & Irregular shape and size & Suzuki coupling reaction & [98] \\
\hline
\end{tabular}

In 2021, Veisi and co-workers presented the catalytic activity of $\mathrm{Fe}_{3} \mathrm{O}_{4} @$ Gritillara/PdNPs, in the reduction of nitroarenes in $\mathrm{H}_{2} \mathrm{O} / \mathrm{EtOH}$ (2:1) as a medium. The magnetic nanocatalyst was obtained using a Fritillaria imperialis flower extract as the reducing and capping agent in the in-situ formation of PdNPs on the surface of $\mathrm{Fe}_{3} \mathrm{O}_{4}$ MNPs [80]. The catalyst was recovered and reused for 8 cycles without a noticeable loss in activity. The particles' size and shape were retained and no agglomeration was observed.

In 2018, the same authors reported the use of tannic acid as the reducing and stabilizing agent for the immobilization of PdNPs on $\mathrm{Fe}_{3} \mathrm{O}_{4}$ MNPs [82]. The nanocatalyst has been used in the Suzuki coupling reaction and in the reduction of 4-nitrophenols in an aqueous medium. There was not a noticeable reduction of catalytic activity observed for up to 8 and 10 cycles, respectively.

In 2020, Hemmati and co-workers developed the in-situ formation of PdNPs over the surface of $\mathrm{Fe}_{3} \mathrm{O}_{4}$ magnetic nanoparticles by using a Strawberry fruit extract under ultrasonic

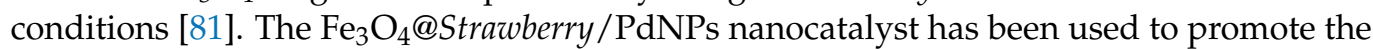
Suzuki reaction efficiently in $\mathrm{H}_{2} \mathrm{O} / \mathrm{EtOH}$ (1:1) as green reaction medium. The preservation of the catalyst's nanostructure and a negligible leaching of $\mathrm{Pd}$ over the reaction runs has been observed.

In 2019, the aqueous extract of Artemisia abrotanum leaf was used by Yousefi and co-workers to produce PdNPs on the surface of reduced graphene oxide (rGO) [85]. Both the graphene oxide support and $\mathrm{Pd}(\mathrm{II})$ ions were reduced by an abrotanum leaf extract. 
The TEM image displayed that rGO are covered with a thin layer of biomolecules which increase the PdNPs dispersibility. The catalytic activity of PdNPs coated on modified rGO was tested in the Suzuki reaction in $\mathrm{H}_{2} \mathrm{O} / \mathrm{EtOH}(1: 1)$ at $50^{\circ} \mathrm{C}$, displaying excellent reaction performances for up to 9 cycles with negligible levels of $\mathrm{Pd}$ leaching.

In 2020, Peng and co-workers used tea and coffee extracts to produce PdNPs on the surface of titanium nanotube arrays (TNAs) under microwave irradiation [90]. The nanocatalyst has been used successfully in photoelectrochemical experiments for the degradation of dyes in the anodic chamber and the simultaneous production of hydrogen in the cathodic chamber. It is shown that the photocurrent of $\mathrm{Pd} / \mathrm{TNAs}-\mathrm{C}$, obtained by using coffee as the reducing agent, was higher than that of $\mathrm{Pd} / \mathrm{TNAs}$, obtained by hydrothermal methods.

The green synthesis of $\mathrm{Pd} / \mathrm{CuONPs}$ via the reduction of a $\mathrm{PdCl}_{2} / \mathrm{CuCl}_{2}(2: 10)$ aqueous solution with Theobroma cacao L. seeds extract and their catalytic application was reported by Nasrollahzadeh in 2015 [92]. The Pd/CuO NPs, with an average size of around $40 \mathrm{~nm}$, presented a good catalytic activity in the Heck coupling reaction for up to six consecutive runs $(98 \rightarrow 92 \%$ yield). However, for the realization of an environmentally sustainable process, a greener solvent should be used instead of dimethylformamide (DMF).

Inorganic supports such as zeolite, hydrotalcites and montmorillonite have been used for the immobilization and stabilization of PdNPs [93-96]. In 2020, the environmentally friendly preparation of PdNP@Zeolite Type-Y [93] was explored by Manjare and Chaudhari, using an aqueous extract of Anacardium Occidentale shell as the reducing and stabilizing agents. Very small PdNPs have been obtained $(1-2 \mathrm{~nm})$ and high catalytic activity and recyclability up to 10 cycles has been observed in the Suzuki reaction of iodobenzene with aryl boronic acid in water at $90{ }^{\circ} \mathrm{C}$ with a $0.01 \mathrm{~mol} \%$ Pd loading (TOF $6100-8400 \mathrm{~h}^{-1}$ ).

In 2017, Nasrollahzadeh and co-workers reported the use of an eggshell as an economic and environmentally friendly support for immobilizing PdNPs prepared using a barberry fruit extract as a reducing and capping agent [97]. The catalytic activity has been evaluated in the hydroxylation of phenylboronic acid and in the reduction of 4-nitrophenol and dyes. High yields and excellent recyclability were observed for up to six cycles in the reduction of 4-nitrophenol. There was no observed morphology alteration of Pd nanocomposite and there was a very low Pd leaching into solution $(<0.1 \%)$.

\subsection{Biopolymers as Supports}

As mentioned, the catalytic properties of PdNPs are closely related both to the shape and size of the nanoparticles and to the nature of the stabilizer. The agglomeration phenomena increase the size of PdNPs and considerably reduce the catalytic activity during use. One proposed solution is to immobilize the PdNPs on the surface of a support with a high surface area. The chelation between the support and the PdNPs stabilizes the nanoparticles and prevents the agglomeration phenomena, consequently increasing the catalytic activity and facilitating its recovery and reuse. Various supports have been developed for anchoring and stabilizing PdNPs such as organic polymers, inorganic materials, organic-inorganic hybrids and carbon materials [4-6,100-104].

Recently, multiple literatures, that have been referenced, report the use of natural polymers as green supports for the sustainable preparation of PdNPs.

Biopolymers such as polysaccharides (cellulose, chitosane, pectine, agarose, starch), lignin, gum, protein and DNA are promising materials as green supports for PdNPs because they are non-toxic, biodegradable, incur a low cost and are abundant in nature and also possess excellent mechanical properties and thermal stability, easing chemical modifications and having a high chelating capacity with metal ions $[32,105,106]$.

The skeletons of these biopolymers are rich in hydroxyl, amino and carboxylic groups which are responsible for the chelation of the Pd ions and for the stabilization of the formed PdNPs. Furthermore, these groups determine the solubility of the Pd nanocatalysts in the reaction medium, a very important property for chemical processes performed in an aqueous medium. 
The biopolymers can be used in their native form or after modification in order to improve the metal coordination, nucleation and stabilization of the metal nanoparticles.

There are three different approaches for the preparation of biopolymer-supported PdNPs. These are (i) impregnating the polymer in its native form or after its modification with the Pd(II) ion salt and an in-situ reduction by hydroxyl groups of biopolymer; (ii) impregnating the biopolymer with the $\mathrm{Pd}(\mathrm{II})$ ion salt followed by the addition of an external reducing agent (iii) synthesis of colloidal PdNPs and then adsorption into biopolymer branches.

The first method is the most convenient and commonly used, in this case the biopolymer acts both as a support and as a reducing agent. The reduction of the Pd (II) ion is generally obtained by thermal heating in an aqueous medium or by using ethanol as a solvent and an in-situ reducing agent. When an external reducing agent is required, from a green perspective, a natural reducing agent from a plant extract is preferred.

Table 3 presents recent reported examples on the use of biopolymers as a support for PdNPs, the method used for PdNPs production and the catalytic application. Some examples are briefly described below.

As presented in Table 3, both native and modified biopolymers have been used as a support for the immobilization of PdNPs, dispersion and stabilization. Generally, the reduction of Pd(II) occurs without the addition of an external reducing agent, the functional groups present in the biopolymer are responsible for the formation of $\operatorname{Pd}(0)$. When an external reductant is required, natural reductants from plant extracts or ethanol reduction are generally used. Only a few examples report the use of chemical reducing agents such as $\mathrm{NaBH}_{4}$. Some examples of the different approaches are described below.

In 2021, Mao and co-workers reported the use of nanocellulose, generated from waste cotton cloth, as a green support for the immobilization and stabilization of small sized PdNPs [107]. The Pd@NC NPs catalyst was generated in situ during the course of the Suzuki reaction in an aqueous medium in the absence of additional reagents. The catalyst showed excellent catalytic activity not only in the Suzuki reaction of aryl iodides and bromides but also with the least reactive aryl chlorides. After the reaction, the in situ generated catalyst was separated and reused for up to 11 cycles without the loss of catalytic activity. The high stability was also confirmed using a hot-filtration test and through an ICP-OES analysis; no leaching of Pd in the aqueous reaction medium was observed.

In 2020, Patil and co-workers reported the preparation of a Pd@cellulose fiber from a waste banana pseudostem [109]. Pd nanoparticles, that were biogenically prepared from a banana pseudostem extract, were immobilized on cellulose fibers from waste banana pseudostem. An excellent catalytic activity was observed in the Suzuki coupling reaction at room temperature, in $\mathrm{H}_{2} \mathrm{O} / \mathrm{EtOH}(1: 1)$ as green reaction medium with only a $0.004 \mathrm{~mol} \%$ Pd loading. The catalyst has been recycled for up to 15 times without losing its catalytic activity. A hot filtration test and $<0.01 \mathrm{ppm}$ Pd leaching in the reaction media confirm that PdNPs were tightly trapped in the cellulose fibers. The same catalyst has also been used, by the same authors, in the denitrogenative cross-coupling reaction [110].

In 2020, Bai and Wang reported the preparation of bio-supported Pd nanoparticles where the powder of Clove leaves (RCL) was used as the support, reducing and stabilizing agents [113]. A high catalytic activity and a recyclability for up to 8 cycles has been observed in the Suzuki reaction in $\mathrm{H}_{2} \mathrm{O} / \mathrm{EtOH}(1: 1)$ at $60{ }^{\circ} \mathrm{C}$ with a $0.05 \mathrm{~mol} \% \mathrm{Pd}$ loading (TOF $5773.2 \mathrm{~h}^{-1}$ ). The pore structure and the oxygen-containing groups on the RCL greatly improve the stability and recyclability of the small-sized PdNPs and facilitates the mass transfer of the substrate, thus improving the catalytic activity. 
Table 3. Green synthesis of supported PdNPs on various biopolymers and their applications.

\begin{tabular}{|c|c|c|c|c|}
\hline Biopolymer & Reducing Agent & Size of PdNPs & Catalytic Application & Reference \\
\hline $\begin{array}{l}\text { Nanocellulose from waste } \\
\text { cotton cloth }\end{array}$ & - & $2.46 \mathrm{~nm}$ & Suzuki coupling reaction & [107] \\
\hline Cyclea barbata pectin & - & $6-12 \mathrm{~nm}$ & $\begin{array}{l}\text { Heck coupling reaction } \\
\text { Reduction of nitrophenols }\end{array}$ & [108] \\
\hline $\begin{array}{l}\text { Cellulose from waste banana } \\
\text { pseudostem }\end{array}$ & $\begin{array}{l}\text { Waste banana pseudostem } \\
\text { extract }^{a}\end{array}$ & $8-18 \mathrm{~nm}$ & $\begin{array}{l}\text { Suzuki coupling reaction } \\
\text { Denitrogenative } \\
\text { cross-coupling }\end{array}$ & {$[109,110]$} \\
\hline Chitosan nanofiber & $\mathrm{EtOH}$ & $5-50 \mathrm{~nm}$ & $\begin{array}{l}\text { Suzuki and Heck coupling } \\
\text { reaction }\end{array}$ & [111] \\
\hline Brown cotton fiber & - & $8 \mathrm{~nm}$ & Suzuki coupling reaction & [112] \\
\hline Clove leaf powder & - & $4.49 \mathrm{~nm}$ & Suzuki coupling reaction & [113] \\
\hline $\begin{array}{c}\text { Chitosan/agarose/beta- } \\
\text { cyclodextrin } \\
\text { microbeads }\end{array}$ & $\mathrm{EtOH}$ & $50 \mathrm{~nm}$ & Suzuki coupling reaction & [114] \\
\hline Xylose hydrocar microsphere & $\mathrm{EtOH}$ & $8-18 \mathrm{~nm}$ & Suzuki coupling reaction & [115] \\
\hline$\left(\mathrm{Pd}_{4}\right)_{3}$-GFPuv fusion protein & $\mathrm{NaBH}_{4}$ & $2.4 \pm 0.7$ & $\begin{array}{l}\text { Suzuki and Stille coupling } \\
\text { reaction }\end{array}$ & [116] \\
\hline Oxytocin & - & $16-18 \mathrm{~nm}$ & Suzuki coupling reaction & [117] \\
\hline $\begin{array}{c}\text { Modified Nonpareil almond } \\
\text { shell }\end{array}$ & $\begin{array}{l}\text { Nonpareil almond hull } \\
\text { extract }\end{array}$ & $20 \mathrm{~nm}$ & Reduction of Dyes & [118] \\
\hline Jute plant sticks & $\mathrm{NaBH}_{4}$ & $7-10 \mathrm{~nm}$ & $\begin{array}{c}\text { Suzuki and Heck coupling } \\
\text { reaction }\end{array}$ & [119] \\
\hline Jute plant sticks & $\mathrm{HCOOH}$ & $15-20 \mathrm{~nm}$ & $\begin{array}{l}\text { Hydrogenation of olefins and } \\
\text { N-heteroarenes }\end{array}$ & [120] \\
\hline Lentinan & - & $2.3-3.3 \mathrm{~nm}$ & Reduction of 4-nitrophenol & [121] \\
\hline Collagen & - & $20-25$ & Suzuki coupling reaction & [122] \\
\hline Lignin & - & $1-5 \mathrm{~nm}$ & Sonogashira & [123] \\
\hline Gum gatti & - & $4.8 \pm 1.6$ & $\begin{array}{l}\text { Reduction of 4-nitrophenol } \\
\text { and dyes }\end{array}$ & [124] \\
\hline $\begin{array}{l}\text { Carboxymethyl } \\
\text { cellulose/agar }\end{array}$ & - & $37-55 \mathrm{~nm}$ & Suzuki coupling reaction & [125] \\
\hline $\begin{array}{c}\text { Chitosan/cellulose } \\
\text { composite }\end{array}$ & $\mathrm{NaBH}_{4}$ & $26-30$ & Suzuki coupling reaction & [126] \\
\hline Chitosan/starch composite & $\mathrm{NaBH}_{4}$ & $16-21 \mathrm{~nm}$ & Suzuki coupling reaction & [127] \\
\hline Residue of Poplar leaf & Poplar leaf extract & $3.1 \mathrm{~nm}$ & Suzuki coupling reaction & [128] \\
\hline Gum Arabic/pectin beads & - & $3-6 \mathrm{~nm}$ & Heck coupling reaction & [129] \\
\hline Pine needle powder & Pine needle extract & $3.25 \mathrm{~nm}$ & Suzuki coupling reaction & [130] \\
\hline $\begin{array}{c}\text { Pentacyclic triterpenoid } \\
\text { arjunolicacid from Terminalia } \\
\text { arjuna }\end{array}$ & $\begin{array}{c}\text { Chrysophyllum caimito leaf } \\
\text { extract }\end{array}$ & $9 \mathrm{~nm}$ & $\begin{array}{l}\text { Suzuki and Heck coupling } \\
\text { reaction }\end{array}$ & [131] \\
\hline Oak gum & - & $5-7 \mathrm{~nm}$ & $\begin{array}{l}\text { Suzuki coupling reaction } \\
\text { Reduction of nitroarenes }\end{array}$ & [132] \\
\hline $\begin{array}{l}\text { Carboxymethyl } \\
\text { functionalized } \\
\text { hemicelluloses }\end{array}$ & $\mathrm{EtOH}$ & $11-19$ & Heck coupling reaction & [133] \\
\hline $\begin{array}{l}\text { Native and modified } \\
\text { Chitosan microspheres }\end{array}$ & $\mathrm{EtOH}$ & $5 \mathrm{~nm}$ & Sonogashira coupling reaction & [134] \\
\hline Cellulose & $\begin{array}{l}\text { hearth wood extract of } \\
\text { Artocarpus lakoocha Roxb }\end{array}$ & $10-30 \mathrm{~nm}$ & $\begin{array}{l}\text { Suzuki and Heck coupling } \\
\text { reaction }\end{array}$ & [135] \\
\hline Pistacia atlantica kurdica gum & $\mathrm{EtOH}$ & $4-7 \mathrm{~nm}$ & $\begin{array}{l}\text { Suzuki and Heck coupling } \\
\text { reaction }\end{array}$ & [136] \\
\hline Thiourea modified chitosan & Ellagic acid & $3-5 \mathrm{~nm}$ & Suzuki coupling reaction & [137] \\
\hline Gelatin/pectin & - & $2-5 \mathrm{~nm}$ & Heck coupling reaction & [138] \\
\hline DNA & - & $7.1 \pm 3.5$ & Sonogashira coupling reaction & [139] \\
\hline
\end{tabular}

${ }^{a}$ Preformed biogenically synthesized palladium nanoparticles were immobilized on cellulose. 
In the same year, Baran and Nasrollahzadeh reported a green procedure for the synthesis of PdNPs on biodegradable microbeads consisting of chitosan, agarose and beta-cyclodextrin (CAP) [114]. The pendant hydroxyl and amino groups on the matrices strongly interact with the palladium, producing a highly active, recyclable catalyst for the Suzuki reaction. High yields of biphenyls have been obtained by using a green procedure without the presence of solvents (solvent free conditions), under microwave irradiation for 6 min. After 7 cycles the catalyst retains its spherical surface and a negligible level of Pd leaching was observed.

In 2020, recombinant 45-amino acid long peptides that were fused to a green fluorescent protein (GFPuv) were used by Beyzavi and co-workers to control the size, morphology, and structure of the PdNPs formation [116]. Histidine residues present in the protein structure inhibit the growth of nanoparticles resulting in PdNPs with an average size of $2.4 \mathrm{~nm}$. The catalytic activity was evaluated in the Suzuki and Stille coupling reaction in $\mathrm{H}_{2} \mathrm{O} / \mathrm{EtOH}$ as the reaction medium. A slight decrease of catalytic performance was observed over 5 runs. Also, no aggregation or morphological changes were observed in the used catalyst after five cycles.

In 2019, Javanshir and co-workers reported the use of Isinglass, containing approximately $98 \%$ protein collagen, as a reducing and stabilizing agent for PdNPs production [122]. The catalytic activity of the Pd/IG biocatalyst was tested using the Suzuki reaction with water as the reaction medium. The recovery and reuse were successfully achieved in 5 successive runs. The TEM image of the recovered catalyst showed that both the morphology and size of PdNPs does not vary significantly.

In 2018, Baran and co-workers designed green chitosan/starch and chitosan/cellulose composites as supports for the stabilization of Pd nanoparticles obtained through the reduction of $\mathrm{Na}_{2} \mathrm{PdCl}_{4}$ with $\mathrm{NaBH}_{4}$ in an aqueous solution [126,127]. The obtained $\mathrm{Pd} @$ chitosan/starch and Pd@chitosan/cellulose nanocomposites were employed in a very low Pd loading (0.005 mol\% and $0.004 \mathrm{~mol} \%$, respectively) in the Suzuki reaction under microwave heating, in solvent-free conditions, for $5 \mathrm{~min}$. Further, an excellent reactivity was observed (TOF $\sim 300,000-170,000 \mathrm{~h}^{-1}$ ) for the less reactive aryl chloride. The recovery and reuse of $\mathrm{Pd}$ nanocatalysts has been explored: while Pd@chitosan/starch showed a decrease in catalytic activity already at the 4th run, Pd@chitosan/cellulose retained its catalytic activity and structures for up to 8 cycles. For a totally green strategy, a sustainable green reducing agent, in place of $\mathrm{NaBH}_{4}$, is highly desirable.

In some examples, a significant reduction of the catalytic activity was observed during the recovery and reuse tests. Pd leaching and/or the agglomerating of PdNPs are often responsible for the decreased conversion of desired products as suggested by the TEM images and leaching studies [108,111,115,125,128,131,135].

Recently, DNA has received a great deal of attention in the field of catalysis because of its ability to act as a ligand for metal complex formation or as a support for metal nanoparticles $[140,141]$. Indeed, the phosphate groups and nitrogen-rich bases that are present in DNA have a high affinity for transition metals.

In 2017, Alonso and co-workers prepared a PdNPs/DNA nanocatalyst for the copperand ligand-free Sonogashira coupling reaction [139]. The catalyst was easily recovered and reused in five cycles and a drop of the yield was observed in the 5 th run. The palladium content in the solution was determined to be only $0.01 \mathrm{wt} . \%$ of the original amount.

More stable and monodisperse PdNPs can be obtained by using biopolymers as coating agent to modify the surface of solid supports such as magnetic nanoparticles, graphite, metal oxides and natural clays.

Recent examples on synthesis and catalytic application of PdNPs immobilized on biopolymer-solid support nanocomposites are reported in Table 4. 
Table 4. Biopolymers as stabilizing and dispersing agent for PdNPs production on the surface of solid supports.

\begin{tabular}{|c|c|c|c|c|}
\hline Support & Biopolymer/Reducing Agent & Size of PdNPs & Catalytic Application & Reference \\
\hline \multirow{12}{*}{$\mathrm{Fe}_{3} \mathrm{O}_{4}$ magnetic NPs } & Chitosan-Starch & $5-6 \mathrm{~nm}$ & $\begin{array}{l}\text { Suzuki coupling reaction } \\
\text { Reduction of 4-nitrophenol }\end{array}$ & [142] \\
\hline & Modified Chitosan $\left(\mathrm{NaBH}_{4}\right)$ & $60 \mathrm{~nm}$ & $\begin{array}{l}\text { Suzuki and Heck coupling } \\
\text { reaction }\end{array}$ & [143] \\
\hline & Modified Cellulose $\left(\mathrm{NaBH}_{4}\right)$ & $6-8 \mathrm{~nm}$ & $\begin{array}{l}\text { Suzuki and Sonogashira coupling } \\
\text { reaction }\end{array}$ & [144] \\
\hline & Lignin & $5-10 \mathrm{~nm}$ & Heck coupling reaction & [145] \\
\hline & Lignin-Chitosan (EtOH) & $<20 \mathrm{~nm}$ & Suzuki coupling reaction & [146] \\
\hline & Chitosan-activated carbon & $31-48$ & Suzuki coupling reaction & [147] \\
\hline & Chitosan-Agar & $28-39$ & $\begin{array}{l}\text { Suzuki coupling reaction } \\
\text { Reduction of 4-nitrophenol }\end{array}$ & [148] \\
\hline & Polysaccharides from algae & $25-35$ & Suzuki coupling reaction & [149] \\
\hline & Modified Chitosan (EtOH) & $6-7 \mathrm{~nm}$ & $\begin{array}{l}\text { Suzuki and Sonogashira coupling } \\
\text { reaction }\end{array}$ & [150] \\
\hline & Modified Salep $\left(\mathrm{NaBH}_{4}\right)$ & $5 \mathrm{~nm}$ & Suzuki coupling reaction & [151] \\
\hline & Modified Chitosan (EtOH) & $31 \mathrm{~nm}$ & $\begin{array}{l}\text { Suzuki and Heck coupling } \\
\text { reaction }\end{array}$ & [152] \\
\hline & DNA & $11-15 \mathrm{~nm}$ & Suzuki coupling reaction & [153] \\
\hline$\delta$-FeOOH Magnetic & Chitosan $(\mathrm{EtOH})$ & $10 \mathrm{~nm}$ & Suzuki coupling reaction & [154] \\
\hline $\mathrm{Fe}_{3} \mathrm{O}_{4} / \mathrm{SiO}_{2}$ & Polydopamine & $5 \mathrm{~nm}$ & $\begin{array}{l}\text { Suzuki coupling reactions } \\
\text { Reduction of 4-nitrophenol }\end{array}$ & [155] \\
\hline Graphene QD & Chitosan $\left(\mathrm{NaBH}_{4}\right)$ & $6-8 \mathrm{~nm}$ & Reduction of nitroarenes & [156] \\
\hline Graphene nanosheet & Cyclodextrin (EtOH) & $5-15 \mathrm{~nm}$ & $\begin{array}{l}\text { Suzuki and Heck coupling } \\
\text { reaction }\end{array}$ & [157] \\
\hline \multirow{2}{*}{ Carbon Nanotube } & Chitosan $(\mathrm{EtOH})$ & not reported & $\begin{array}{l}\text { Suzuki coupling reactions } \\
\text { Reduction of nitroarene and dyes }\end{array}$ & [158] \\
\hline & DNA $\left(\mathrm{NaBH}_{4}\right)$ & not reported & $\begin{array}{l}\text { Suzuki and Sonogashira coupling } \\
\text { reaction }\end{array}$ & [159] \\
\hline Kaolin & Modified Chitosan (EtOH) & $15-20 \mathrm{~nm}$ & Sonogashira coupling reaction & [160] \\
\hline Bentonite & Chitosan $(\mathrm{EtOH})$ & $13 \pm 2$ & Sonogashira coupling reaction & [161] \\
\hline MMT & Chitosan & $5 \mathrm{~nm}$ & Sonogashira coupling reaction & [162] \\
\hline
\end{tabular}

Similarly, the reduction of $\mathrm{Pd}(\mathrm{II})$ ions is achieved through thermal heating in an aqueous medium without adding any reducing agent or by using ethanol as the solvent and reductant. In some cases, the addition of an external reducing agent is required. Some examples are briefly described below.

Biopolymer functionalized $\mathrm{Fe}_{3} \mathrm{O}_{4}$ nanocomposite can assist in obtaining nanocatalysts with a high performance both in terms of catalytic activity and recyclability.

In 2021, Veisi and co-workers synthesized a novel PdNPs-adorned chitosan-starch encapsulated core-shell type magnetic nanocomposite $\left(\mathrm{Fe}_{3} \mathrm{O}_{4} @ \mathrm{CS}-\mathrm{Starch} / \mathrm{Pd}\right)$ without any reducing agent, by applying ultrasound irradiations [142]. Excellent performance has been obtained both in the Suzuki coupling reaction and in the reduction of 4-nitrophenol under sonication. The catalyst was easily magnetically recovered and reused for 11 cycles, with a slight decrease observed only after 9th cycle. A hot filtration test and Pd content displayed that the catalyst was truly heterogeneous without a significant leaching of the active species.

In 2020, Hasan prepared a magnetic nanocatalyst through the immobilization of chitosan (CS) on a magnetic $\mathrm{Fe}_{3} \mathrm{O}_{4}$ following the deposition of PdNPs on its modified surface by using $\mathrm{NaBH}_{4}$ as the reducing agent [143]. A high catalytic activity was observed both in the Suzuki and Heck coupling reactions in $\mathrm{H}_{2} \mathrm{O} / \mathrm{EtOH}$ (4:1). The catalyst was magnetically recovered and reused up to seven times in the Suzuki coupling reactions with $97 \%$ efficiency.

Conversely, in the same year, Heydari synthesized a magnetic nanocatalyst, immobilizing PdNPs on the surface of phosphine-functionalized cellulose (PFC) by using $\mathrm{NaBH}_{4}$ 
as the reducing agent, followed by the deposition of PFC-Pd on the surface of the $\mathrm{Fe}_{3} \mathrm{O}_{4}$ magnetic nanoparticles [144]. The catalytic performances have been evaluated in the Sonogashira and Suzuki coupling reactions in a $\mathrm{K}_{2} \mathrm{CO}_{3} /$ glycerol (1:5) deep eutectic solvent (DES), used as a green solvent. The catalyst was simply recovered by magnetic filtration and reused for up to five cycles without a significant loss of activity.

Between 2019 and 2020, Baran and co-workers synthesized various palladium nanocatalyst anchored on magnetically separable lignin-chitosan beads [146], chitosan/activated carbon microcapsules [147] and chitosan/agar microcapsules [148]. The catalytic activity has been evaluated on a microwave-assisted Suzuki coupling reaction under solvent free conditions. High performances have been observed for all palladium magnetic nanocatalysts, but the greatest results were obtained using PdNPs@CS-AC/ $/ \mathrm{Fe}_{3} \mathrm{O}_{4}$ [147] where both chitosan and activated carbons with a high surface area and microporous structure provide the coordination sites for PdNPs. The Pd magnetic nanocatalyst retained its catalytic performance even after ten successive runs ( $99 \rightarrow 95 \%$ yield) with only $0.5 \%$ Pd leaching. There was no change observed in surface morphology of microcapsules and the shape and size of PdNPs.

In 2021, the same authors used an eco-friendly and low-cost magnetic nanocomposite consisting of a chitosan and magnetic iron oxyhydroxide microsphere, $\delta$ - $\mathrm{FeOOH}$, to immobilize palladium nanoparticles [154]. The prepared catalyst has been tested in the Suzuki reaction in $\mathrm{H}_{2} \mathrm{O} / \mathrm{EtOH}(1: 1)$ at $70{ }^{\circ} \mathrm{C}$ with $0.05 \mathrm{~mol} \%$ Pd loading. High catalytic activity and a recyclability for up to 8 cycles has been obtained. FE-SEM, TEM, and FT-IR analyses indicate that the magnetic microspheres retain their structure without any significant changes compared with the fresh one.

In 2018, Farzada and Veisi used $\mathrm{Fe}_{3} \mathrm{O} 4 / \mathrm{SiO}_{2}$ nanoparticles, coated with polydopamine (PDA), obtained by simple green self-polymerization of dopamine on magnetic support, to immobilize PdNPs [155]. The phenolic hydroxyl and amine functional groups on the surface of PDA act as the adsorbent, reducing and stabilizing agent for the production of PdNPs. The Pd-nanocomposite was conveniently recovered and reused for twelve runs, with a minor reduction in catalytic activity after the tenth cycle, in the Suzuki coupling reaction in $\mathrm{H}_{2} \mathrm{O} / \mathrm{EtOH}(1: 1)$ at $40{ }^{\circ} \mathrm{C}$.

Graphene quantum dots (GQDs) have emerged as a new class of promising organic nanomaterials due to their high stability, interesting surface area, low-toxicity and biocompatibility. In 2021, a new palladium nanocatalyst was obtained by Keshipour and co-workers by building graphene quantum dots on a citric acid modified chitosan via a citric acid self-condensation reaction and the successive deposition of PdNPs by the chemical reduction of $\mathrm{Pd}$ (II) with $\mathrm{NaBH}_{4}$ [156]. The catalyst exhibited excellent catalytic activity and selectivity in the reduction of nitroarenes in a mild reaction condition using water as a green solvent. The catalyst has been recovered and reused for up to 5 cycles with a negligible loss of activity and very low Pd leaching in solution. GQD assists the stability of PdNPs because of extensive electronic system on its structure.

Natural clay such as kaolin, bentonite and montmorillonite has been used as support to increase the stabilization of PdNPs-decorated chitosan (CS) [160-162]. A comparative catalytic study in the Sonogashira reaction between aryl iodides and alkynes in the presence of CS/Pd and CS/MMT/Pd was reported by Qi and co-workers in 2015 [162]. The stabilization of montmorillonite (MMT) effectively improved the thermal stability and $\mathrm{Pd}$ leaching resistance of the hybrid catalysts. Indeed, the CS/Pd catalyst showed a decline of catalytic activity after only the 4 th run while the stabilized CS/MMT/Pd can be recycled 10 times without a significant decrease in yield. Moreover, CS/MMT/Pd showed a much lower Pd leaching percentage than CS/Pd.

In 2020, Patil designed a Pd/DNA bio-nanocatalyst, exploiting the metal chelating properties of DNA, immobilized on silyl functionalized $\mathrm{Fe}_{3} \mathrm{O}_{4}$ magnetic nanoparticles, to graft and stabilize PdNPs [153]. The prepared catalyst was tested in the Suzuki reaction in $\mathrm{H}_{2} \mathrm{O} / \mathrm{EtOH}$ (1:1) at room temperature with a $0.02 \mathrm{~mol} \% \mathrm{Pd}$ loading. Excellent reactivity 
and recyclability have been obtained for up to six cycles, and a slight drop in the yield was observed thereafter.

In 2019, Hajipour and Khorsandi report the use of a DNA-modified multi-walled carbon nanotubes (MWCNTs) to immobilize and stabilize PdNPs [159]. The aromatic nucleobases of DNA interact through $\pi-\pi$ stacking with the surface of carbon nanotubes and stabilize palladium nanoparticles. The evaluation of catalytic activity has been performed in a Suzuki and Sonogashira coupling reaction in $\mathrm{H}_{2} \mathrm{O} / \mathrm{EtOH}(1: 1)$ at $65{ }^{\circ} \mathrm{C}$ in the presence of a $0.024 \mathrm{~mol} \% \mathrm{Pd}$ loading. High yields were also obtained with less reactive aryl chloride. The catalyst was recovered and reused seven times with a slight decrease in the yield after the 6 th cycle $(98 \rightarrow 86 \%$ yield). Neither a spectroscopic analysis nor $\mathrm{Pd}$ leaching measurements were performed on the recovered catalyst.

\subsection{Carbonaceous Supports}

Carbonaceous materials such as mesoporous active carbon, graphene, carbon nanotube and carbon quantum dots (CDQ), have attracted considerable attention due to some important advantages such as high availability and low cost, biocompatibility, high surface areas, their porous structure and high thermal, mechanical and chemical stability [6,103]. Their unique pore structure can allow to obtain very small and dispersed metal nanoparticles and can increase the performance of a nanocatalyst, thereby enhancing the contact between the reactants and the catalyst, imparting an overall synergistic effect. These unique features have made carbonaceous materials interesting supports for the immobilization of palladium NPs. As of quite recently, bio-wastes have been used as a source for the preparation of mesoporous carbon active supports for PdNPs catalysts that prove to be inexpensive, renewable and biodegradable.

Table 5 presents recent examples of green carbonaceous materials used as supports for palladium NPs, listing the used bio-source and their catalytic application.

Table 5. Green synthesis of supported PdNPs on carbonaceous materials and their applications.

\begin{tabular}{|c|c|c|c|c|}
\hline Carbonaceous Material & Bio-Source & $\begin{array}{l}\text { Size of } \\
\text { PdNPs }\end{array}$ & Catalytic Application & Reference \\
\hline Porous active carbon & pine needle urban waste & $4.5 \mathrm{~nm}$ & Heck and Hiyama coupling reaction & [163] \\
\hline Modified biochar & dried chicken manure & $6-8 \mathrm{~nm}$ & Suzuki and Heck coupling reaction & [164] \\
\hline Mesoporous carbon & phenolic resin & $1.2 \mathrm{~nm}$ & Suzuki coupling reaction & [165] \\
\hline Activated mesoporous carbon & Rice husk biomass & $7 \mathrm{~nm}$ & Suzuki, Heck and Sonogashira coupling reaction & [166] \\
\hline Carbon-SiO 2 & Rice husk biomass & $3.5-4.5 \mathrm{~nm}$ & Carbonylative Suzuki coupling reaction & {$[167]$} \\
\hline $\mathrm{Fe}_{3} \mathrm{O}_{4} @$ Porous Carbon & Pomegranate peel waste. & not reported & Suzuki and Sonogashira coupling reaction & [168] \\
\hline Mesoporous carbon & Tannin & $25 \mathrm{~nm}$ & Suzuki coupling reaction & [169] \\
\hline $\mathrm{CDQ} @ \mathrm{Fe}_{3} \mathrm{O}_{4}$ & Glycerol/urea & $15-20 \mathrm{~nm}$ & $\begin{array}{l}\text { Suzuki coupling reaction } \\
\text { Reduction of nitroarenes }\end{array}$ & [170] \\
\hline $\mathrm{CQD} @ \mathrm{Fe}_{3} \mathrm{O}_{4}$ & Vanillin & $3.6 \mathrm{~nm}$ & Suzuki coupling reaction & [171] \\
\hline $\mathrm{CDQ} @ \mathrm{Fe}_{3} \mathrm{O}_{4}$ & Citric acid/urea & $20 \mathrm{~nm}$ & Suzuki coupling reaction & [172] \\
\hline $\mathrm{rGO}$ & - & $2 \mathrm{~nm}$ & Suzuki and Ulman reaction & [173] \\
\hline
\end{tabular}

In 2021, Vaccaro and co-workers report a simple protocol for the valorization of a pine needle urban biowaste [163]. The lignocellulosic biomass is efficiently transformed into biochar, a low-cost support for the immobilization of Pd nanoparticles without adding any reducing agent. The catalytic efficiency was evaluated in Heck and Hiyama coupling reactions in GVL ( $\gamma$-valerolactone), a biomass-derived solvent, comparing the obtained results with commercial $\mathrm{Pd} / \mathrm{C}$ catalyst. The biocatalyst presented a good catalytic efficiency for five consecutive runs in the Heck reaction with a very low average Pd leaching.

In 2019, biochar from dried chicken manure was prepared by Hajjami and co-workers [164]. Surface modified biochar was used as a support to immobilize PdNPs by using $\mathrm{NaBH}_{4}$ as the reducing agent. The catalytic efficiency of the prepared bio-catalyst has been evaluated in a Suzuki and Heck reaction, using polyethylene glycol (PEG) as the green reaction medium. The catalyst was recovered and reused for up to seven successive reaction runs without a significant change in its activity. The amount of palladium in the recovered 
catalyst was in corresponded well with the fresh catalyst, confirming that leaching of the palladium did not occur.

In the same year, Becht and co-workers reported the preparation of a mesoporous carbon support through a self-assembly route, starting with a solution containing a surfactant and a phenolic resin based on phloroglucinol-glyoxal [165]. The biocatalyst with uniformly dispersed ultra-small PdNPs $(1.2 \mathrm{~nm})$ presented an excellent catalytic activity

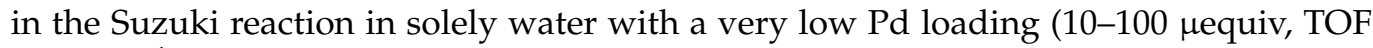
$\left.10,000 \mathrm{~h}^{-1}\right)$. The Pd content in the final product was less than $0.25 \mathrm{ppm}$.

In 2019, an activated mesoporous carbon was synthesized from a rice husk biomass by Banerjee and co-workers [166]. The carbon-based support was decorated with palladium nanoparticles by reducing $\mathrm{PdCl}_{2}$ with $\mathrm{NaBH}_{4}$ and the as-prepared biocatalyst, tested in the Suzuki, Heck and Sonogashira coupling reactions in water or EtOH using microwave irradiation. The catalyst was recovered and reused for up to eight runs but a loss in yield was observed after the fifth cycle. The reduction of catalytic activity has been associated with the agglomeration of PdNPs and a loss of porosity in the mesoporous carbon support.

In 2018, Burri and co-workers used rice husk waste to obtain a C-SiO ${ }_{2}$ support for the deposition of PdNPs via its impregnation with $\mathrm{PdCl}_{2}$ and a successive reduction with hydrazine [167]. The catalytic activity was evaluated in the carbonylative Suzuki coupling reaction in dioxane for the formation of biaryl ketones. Complete conversion was obtained for up to 4 cycles and only a very slight decrease $(98 \%)$ was observed at the 5th cycle.

In the same year, Pourjavadi and Habibi synthesized porous carbon material through the carbonization of pomegranate peel waste [168]. The surface of the carbon support was decorated first with $\mathrm{Fe}_{3} \mathrm{O}_{4}$ nanoparticles providing magnetically separable catalyst and then with PdNPs via the reduction of $\mathrm{Pd}(\mathrm{II})$ with sodium lauryl sulfate (SDS). High catalytic activity and recyclability was obtained in the Suzuki reaction in $\mathrm{EtOH} / \mathrm{H}_{2} \mathrm{O}(1: 1)$ in the presence of a $0.02 \mathrm{~mol} \%$ Pd loading without a significant change in the morphology of the catalyst even after seven runs.

In 2015, Becht and co-workers reported the synthesis of a palladium-containing mesoporous carbon catalyst through a one-step green synthesis based on a soft templating approach, using tannin as the bio-source carbon precursor without the use of toxic crossliker and reducing agents [169]. The catalyst has been successfully used in the Suzuki coupling reaction in propane-1,2-diol as a green solvent in the presence of an extremely

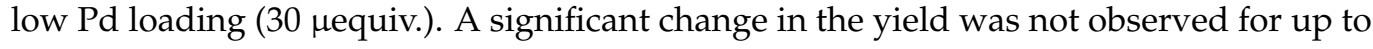
5 runs.

Recently, carbon quantum dots (CQD) have emerged as a green, non-toxic, abundant, and an inexpensive new class of carbon nanomaterials. The carboxylic and hydroxyl groups on the CQDs can act as a reducing and capping agent and confer high water solubility as well as biocompatibility, making it an excellent support for the immobilization of palladium nanoparticles [174].

In recent years, Gholinejad and co-workers prepared CQDs using various green and low-cost sources such as citric acid [172], vanillin [171] or glycerol/urea [170] for the modification of magnetic $\mathrm{Fe}_{3} \mathrm{O}_{4}$ NPs. The magnetically separable supports have been used to immobilize and stabilize PdNPs. The catalytic activity has been evaluated in the Suzuki coupling reaction in $\mathrm{H}_{2} \mathrm{O} / \mathrm{EtOH}$ (1:1) and the optimum result were obtained for the palladium supported on the magnetic $\mathrm{Fe}_{3} \mathrm{O}_{4}$ nanoparticles modified with nitrogendoped CQD obtained from glycerol and urea [170]. The catalyst were recovered and reused for up to 10 cycles with a very small decrease in performance. A hot filtration and poisoning test highlighted that the reactions occur via a release and catch mechanism in which leached active $\operatorname{Pd}(0)$ species catalyze the reaction, and the return of the Pd from the reaction medium to support is responsible for its recycling. The catalyst has also been used in the reduction of nitrophenol in $\mathrm{H}_{2} \mathrm{O} / \mathrm{EtOH}$ (5:1) with a very low Pd loading $(0.008 \mathrm{~mol} \%$ at room temperature). An excellent yield and recyclability were obtained for seven consecutive runs. 
In 2020, Zhang and co-workers developed a simple and green in situ reduction approach for the preparation of reduced graphene oxide supported palladium nanoparticles (Pd/rGO) [173]. Sodium dodecyl sulfate was used to disperse rGO in the solution and after heating, it decomposed to 1-dodecanol, which can reduce $\mathrm{Pd}(\mathrm{II})$ to $\mathrm{Pd}(0)$ by self-oxidization, to dodecanoic acid. The as-prepared catalyst has been used to promote Ullmann and Suzuki coupling reactions by using aryl chlorides as the reactants in an aqueous media using MW irradiation, presenting even better catalytic performances than homogeneous $\mathrm{Pd}(\mathrm{OAc})_{2}$. Moreover, a recycling test on the Ullmann reaction presented a high catalytic performance for up to five cycles and only a slight decrease in the yield was observed at the sixth run due to the partial agglomeration of PdNPs as displayed by the TEM images.

\subsection{Polyol as Liquid Supports}

Alcohols and polyols have been widely used as solvent, reducing and stabilizing agents for the synthesis of palladium nanoparticles. A recent review described the preparation of Pd based nanomaterials in a polyol medium, focusing on size, morphology and structure and their catalytic application in their coupling and a hydrogenation reaction in polyol solvents [175].

Very recently, Pires and co-workers designed glycerol-based solvents such as glycerol ethers and glycerol-based deep eutectic solvents (DES) for the immobilization and stabilization of Pd nanoparticles in liquid phases (PdNPs/solvent) and as a reaction media for catalytic application $[176,177]$. DES were obtained by mixing a glycerol-derived solvent with a bio-ammonium salt such as choline chloride or $N, N, N$-triethyl-2,3-dihydroxypropan1-aminium chloride.

For the immobilization the Pd-NPs, two strategies have been used. The first involves contacting a dispersion of the Pd nanoparticles on poly-N-vinylpyrrolidone (PVP/PdNPs), prepared previously using EtOH as the reducing agent and PVP as the stabilizer, with the glycerol ethers or DES [176]. The dispersion of PdNPs in a glycerol-based solvent avoided a palladium agglomeration, allowing for the creation of a homogeneous PVP$\mathrm{Pd}-\mathrm{NPs} /$ solvent system which was tested using the Heck coupling reaction. After the extraction of the reaction product with $n$-pentane, the PdNPs that were immobilized onto a glycerol-derived solvent were applied to a new catalytic cycle by simply adding new reagents. The best results were observed with the DES obtained from glycerol and isopropyl glyceryl monoethers with $N, N$-triethyl-2,3-dihydroxypropan-1-aminium chloride, and a high yield and recyclability was observed for up to 5 cycles.

In the second approach the $\mathrm{Pd}(\mathrm{II})$ reduction and nucleation was performed in the glycerol-based solvent in the presence of PVP and $\mathrm{H}_{2}$ as the reducing agents, or in a glycerol-derived DES, without adding any reduction or capping agent, thus improving the sustainability for the production of PdNPs. Indeed, the DES acts both as a stabilizer and a liquid support and the small amounts of water present in these hygroscopic solvents would be responsible for the reduction of the palladium ion to $\operatorname{Pd}(0)$ [177]. The as-prepared PdNPs/solvent systems presented high catalytic activity in the hydrogenation of conjugated and nonconjugated alkenes, alkynes, and carbonyl compounds. The DES obtained from methyl glyceryl mono-ethers with $N, N$-triethyl-2,3-dihydroxypropan-1-aminium chloride provided the best results and quantitative conversions were achieved for three consecutive cycles. Palladium agglomeration and a drop of the yield was observed from the fifth run onward.

\subsection{Hydrothermal Coprecipitation}

Hydrothermal coprecipitation is an efficient, one-pot and environmentally sustainable procedure that involves the simultaneous precipitation of the metal precursor and the support material without the addition of a reducing agent.

In 2018, Chatterjee and co-workers developed a convenient method to produce PdNPs on $\gamma-\mathrm{Fe}_{2} \mathrm{O}_{3}$ from $\mathrm{PdCl}_{2}$ and $\mathrm{Fe}_{3} \mathrm{O}_{4}$ magnetic NPs under modified hydrothermal conditions in water at $180^{\circ} \mathrm{C}$ for $48 \mathrm{~h}$ [178]. Magnetic $\mathrm{Fe}_{3} \mathrm{O}_{4}$ reduced the $\mathrm{Pd}(\mathrm{II})$ ions to zerovalent $\mathrm{Pd}$ 
to produce a Pd- $\gamma-\mathrm{Fe}_{2} \mathrm{O}_{3}$ magnetic nanocomposite. The catalyst was tested in a Suzuki reaction with water as the reaction medium and recycled for six runs without a significant loss of catalytic activity until the 5 th cycle.

In 2016, Zhao and co-workers reported a one-pot and eco-friendly hydrothermal procedure for the preparation of a magnetically separable $\mathrm{NiFe}_{2} \mathrm{O}_{4} @ \mathrm{GO}-\mathrm{Pd}$ composite [179]. By using this strategy, the reduction of $\mathrm{PdCl}_{2}$ to $\mathrm{Pd} \mathrm{NPs}$, the conversion of $\mathrm{FeCl}_{3}$ and $\mathrm{NiCl}_{2}$ to $\mathrm{NiFe}_{2} \mathrm{O}_{4}$ magnetic NPs and the deposition on the surface of graphene oxide (GO) were performed simultaneously in an ethanol/ethylene glycol $(49: 1 \mathrm{v} / \mathrm{v})$ at $120{ }^{\circ} \mathrm{C}$ for $24 \mathrm{~h}$. The catalytic activity has been evaluated using a Heck coupling reaction in $\mathrm{EtOH} / \mathrm{H}_{2} \mathrm{O}$ (1:1). Excellent catalytic activity and recyclability was reported for up to six cycles $(99 \rightarrow 95 \%$ yield) with a negligible level of Pd leaching (0.15 wt.\%).

\section{Ultrasonic and Laser Irradiation}

Physical methods such as ultrasound, microwave and laser irradiation are considered to present promising green alternatives to produce PdNPs on the surface of solid supports [27].

In 2020, palladium nanoparticles supported on a magnesium ferrite $\left(\mathrm{Pd} / \mathrm{MgFe}_{2} \mathrm{O}_{4}\right)$ were prepared by Dasari and co-workers using one-pot ultrasound assisted coprecipitation of $\mathrm{FeCl}_{3}, \mathrm{MgCl}_{2}$ and $\mathrm{PdCl}_{2}$ without any reducing and capping agents or surface modifiers [180]. The catalyst has been used to promote the Suzuki reaction in $\mathrm{H}_{2} \mathrm{O} / \mathrm{EtOH}(1: 1)$. A high yield and recyclability, with a negligible level of metal contamination, has been observed for up to 5 cycles.

A green synthesis of palladium NPs immobilized on zeolite-Y by ultrasound irradiation was reported by Tadjarodi in 2018 [181]. High catalytic activity was reported in the Suzuki coupling reaction in $\mathrm{H}_{2} \mathrm{O} / \mathrm{EtOH}(1: 1)$ with a very low Pd loading $(0.02 \mathrm{~mol} \%)$. Moreover, high yields were also obtained with less reactive aryl chlorides and a good yield $(63 \%)$ was obtained with an inactive aryl fluoride. The catalyst was recycled for up to 10 runs without losing the catalytic activity.

In 2021, Tibbetts and co-workers reported the synthesis of uncapped PdNPs through a green procedure that involved a femtosecond laser photoreduction in water of precursor metal salts, such as $\mathrm{K}_{2} \mathrm{PdCl}_{4}$ and $\mathrm{Pd}\left(\mathrm{NO}_{3}\right)_{2}$ [182]. Laser reduction produced ultrasmall colloidal spherical Pd nanoparticles $(3.1 \pm 1.0$ and $1.2 \pm 0.3 \mathrm{~nm}$ using the chloride and nitrate precursors, respectively) and further, anisotropic large aggregates with nanopopcorn and nanoflower morphologies were observed. An exceptionally high level of catalytic activity was obtained in the Suzuki coupling reaction and a reduction of 4-nitrophenol but the colloidal PdNPs proved to be stable for at least a day, therefore, a deposition on solid supports is necessary for future applications.

\section{Conclusions}

In recent years, a growing interest in the development of green and environmentally sustainable procedures has affected all fields of chemistry. Considering the great potential of palladium nanoparticles across many applications, studies regarding their preparation in a sustainable way are constantly growing. The green production of Pd nanoparticles allows for the enhancement of their biological compatibility, the lowering of production costs and the reduction of physiological toxicity and environment pollution.

In this review, the solvent, the reducing agent, the capping and dispersing agent and the synthetic method were the main aspects considered for the synthesis of Pd nanoparticles in a green method.

The use of natural, abundant, easily available and low-cost bio-products as a reductant, stabilizer or support for the immobilization PdNPs certainly responds to the demand for an environmentally friendly and more sustainable synthetic process. Moreover, the use of alternative energy sources such as ultrasound and microwave irradiation are considered for a green perspective. 
The catalytic activity, the recyclability and the robustness of the Pd-nanocatalyst obtained via a green route have been evaluated in sustainable $\mathrm{C}-\mathrm{C}$ coupling reactions and the reduction of nitroarenes. Many Pd-nanocatalysts have presented excellent catalytic activity and recyclability with a very low Pd leaching in solution, promising applicable developments for sustainable and environmentally friendly industrial productions.

Funding: This research received no external funding.

Acknowledgments: This work was supported by the "Università degli Studi di Perugia".

Conflicts of Interest: The author declares no conflict of interest.

\section{References}

1. Kanchi, S.; Ahmed, S. (Eds.) Green Metal Nanoparticles: Synthesis, Characterization and Their Applications; Wiley-Scrivener: Hoboken, NJ, USA, 2018. [CrossRef]

2. El Shafey, A.M. Green synthesis of metal and metal oxide nanoparticles from plant leaf extracts and their applications: A review. Green Process. Synth. 2020, 9, 304-339. [CrossRef]

3. Bej, A.; Ghosh, K.; Sarkar, A.; Knight, D.W. Palladium nanoparticles in the catalysis of coupling reactions. RSC Adv. 2016, 14, 11446-11453. [CrossRef]

4. Luo, S.; Zeng, Z.; Zeng, G.; Liu, Z.; Xiao, R.; Chen, M.; Tang, L.; Tang, W.; Lai, C.; Cheng, M.; et al. Metal Organic Frameworks as Robust Host of Palladium Nanoparticles in Heterogeneous Catalysis: Synthesis, Application, and Prospect. ACS Appl. Mater. Interfaces 2019, 36, 32579-32598. [CrossRef] [PubMed]

5. Hong, K.; Sajjadi, M.; Suh, J.M.; Zhang, K.; Nasrollahzadeh, M.; Jang, H.W.; Varma, R.S.; Shokouhimehr, M. Palladium Nanoparticles on Assorted Nanostructured Supports: Applications for Suzuki, Heck, and Sonogashira Cross-Coupling Reactions. ACS Appl. Nano Mater. 2020, 3, 2070-2103. [CrossRef]

6. Liu, X.; Astruc, D. Development of the Applications of Palladium on Charcoal in Organic Synthesis. Adv. Synth. Catal. 2018, 360, 3426-3459. [CrossRef]

7. Saldan, I.; Semenyuk, Y.; Marchuk, I.; Reshetnyak, O. Chemical synthesis and application of palladium nanoparticles. J. Mater. Sci. 2015, 50, 2337-2354. [CrossRef]

8. Luque, R.; Varma, R.S. (Eds.) Sustainable Preparation of Metal Nanoparticles: Methods and Applications; RSC Green Chemistry; Royal Society Chemistry: Cambridge, UK, 2012. [CrossRef]

9. Vishnukumar, P.; Vivekanandhan, S.; Muthuramkumar, S. Plant-Mediated Biogenic Synthesis of Palladium Nanoparticles: Recent Trends and Emerging Opportunities. ChemBioEng Rev. 2017, 4, 18-36. [CrossRef]

10. Nasrollahzadeh, M.; Sajjadi, M.; Dadashi, J.; Ghafuri, H. Pd-based nanoparticles: Plant-assisted biosynthesis, characterization, mechanism, stability, catalytic and antimicrobial activities. Adv. Colloid Interface Sci. 2020, 276, 102103. [CrossRef]

11. Jadoun, S.; Arif, R.; Jangid, N.K.; Meena, R.K. Green synthesis of nanoparticles using plant extracts: A review. Environ. Chem. Lett. 2021, 19, 355-374. [CrossRef]

12. Md Ishak, N.A.I.; Kamarudin, S.K.; Timmiati, S.N. Green synthesis of metal and metal oxide nanoparticles via plant extracts: An overview. Mater. Res. Express 2019, 6, 112004. [CrossRef]

13. Yadi, M.; Mostafavi, E.; Saleh, B.; Davaran, S.; Aliyeva, I.; Khalilov, R.; Nikzamir, M.; Nikzamir, N.; Akbarzadeh, A.; Panahi, Y.; et al. Current developments in green synthesis of metallic nanoparticles using plant extracts: A review. Artif. Cells. Nanomed. Biotechnol. 2018, 46, S336-S343. [CrossRef]

14. Siddiqi, K.S.; Husen, A. Green Synthesis, Characterization and Uses of Palladium/Platinum Nanoparticles. Nanoscale Res. Lett. 2016, 11, 482. [CrossRef]

15. Hussain, I.; Singh, N.B.; Singh, A.; Singh, H.; Singh, S.C. Green synthesis of nanoparticles and its potential application. Biotechnol. Lett. 2016, 38, 545-560. [CrossRef]

16. Vaccaro, L. (Ed.) Sustainable Flow Chemistry: Methods and Applications; Wiley-VCH Verlag GmbH \& Co: Weinheim, Germany, 2017. [CrossRef]

17. Vaccaro, L.; Curini, M.; Ferlin, F.; Lanari, D.; Marrocchi, A.; Piermatti, O.; Trombettoni, V. Definition of green synthetic tools based on safer reaction media, heterogeneous catalysis, and flow technology. Pure Appl. Chem. 2018, 90, 21-33. [CrossRef]

18. Petrucci, C.; Cappelletti, M.; Piermatti, O.; Nocchetti, M.; Pica, M.; Pizzo, F; Vaccaro, L. Immobilized Palladium Nanoparticles on Potassium Zirconium Phosphate as an Efficient Recoverable Heterogeneous Catalyst for a Clean Heack Reaction in Flow. J. Mol. Catal. A Chem. 2015, 401, 27-34. [CrossRef]

19. Costantino, F.; Vivani, R.; Bastianini, M.; Ortolani, L.; Piermatti, O.; Nocchetti, M.; Vaccaro, L. Accessing stable zirconium carboxyaminophosphonate nanosheets as support for highly active Pd nanoparticles. Chem. Commun. 2015, 51, 15990-15993. [CrossRef]

20. Kozell, V.; Giannoni, T.; Nocchetti, M.; Vivani, R.; Piermatti, O.; Vaccaro, L. Immobilized Palladium Nanoparticles on Zirconium Carboxy-Aminophosphonates Nanosheets as an Efficient Recoverable Heterogeneous Catalyst for Suzuki-Miyaura and Heck Coupling. Catalysts 2017, 7, 186. [CrossRef] 
21. Ferlin, F.; Trombettoni, V.; Luciani, L.; Fusi, S.; Piermatti, O.; Santoro, S.; Vaccaro, L. A waste-minimized protocol for coppercatalyzed Ullmann-type reaction in a biomass derived furfuryl alcohol/water azeotrope. Green Chem. 2018, 20, 1634-1639. [CrossRef]

22. Ferlin, F.; Luciani, L.; Viterritti, O.; Brunori, F.; Piermatti, O.; Santoro, S.; Vaccaro, L. Polarclean as a Sustainable Reaction Medium for the Waste Minimized Synthesis of Heterocyclic Compounds. Front. Chem. 2019, 6, 659. [CrossRef]

23. Ferlin, F.; Cappelletti, M.; Vivani, R.; Pica, M.; Piermatti, O.; Vaccaro, L. Au@zirconium-phosphonate nanoparticles as an effective catalytic system for the chemoselective and switchable reduction of nitroarenes. Green Chem. 2019, 21, 614-626. [CrossRef]

24. Ferlin, F.; Giannoni, T.; Zuliani, A.; Piermatti, O.; Luque, R.; Vaccaro, L. Sustainable Protocol for the Reduction of Nitroarenes by Heterogeneous Au@SBA-15 with NaBH4 under Flow Conditions. ChemSusChem 2019, 12, 3178-3184. [CrossRef]

25. Valentini, F.; Mahmoudi, H.; Bivona, L.A.; Piermatti, O.; Bagherzadeh, M.; Fusaro, L.; Aprile, C.; Marrocchi, A.; Vaccaro, L. Polymer-Supported Bis-1,2,4-triazolium Ionic Tag Framework for an Efficient $\operatorname{Pd}(0)$ Catalytic System in Biomass Derived $\gamma$-Valerolactone. ACS Sustain. Chem. Eng. 2019, 7, 6939-6946. [CrossRef]

26. Campana, F.; Massaccesi, M.B.; Santoro, S.; Piermatti, O.; Vaccaro, L. Polarclean/Water as a Safe and Recoverable Medium for Selective C2-Arylation of Indoles Catalyzed by Pd/C. ACS Sustain. Chem. Eng. 2020, 8, 16441-16450. [CrossRef]

27. Duan, H.; Wang, D.; Li, Y. Green chemistry for nanoparticle synthesis. Chem. Soc. Rev. 2015, 44, 5778-5792. [CrossRef]

28. Ko, Y.L.; Krishnamurthy, S.; Yun, Y.S. Facile synthesis of monodisperse Pt and Pd nanoparticles using antioxidants. J. Nanosci. Nanotech. 2015, 15, 412-417. [CrossRef]

29. Ayad, A.I.; Marín, C.B.; Colaco, E.; Lefevre, C.; Méthivier, C.; Driss, A.O.; Landoulsi, J.; Guénin, E. “Water soluble” palladium nanoparticle engineering for C-C coupling, reduction and cyclization catalysis. Green Chem. 2019, 21, 6646-6657. [CrossRef]

30. Mondal, M.; Begum, T.; Gogoi, P.K.; Bora, U. Gallic Acid Derived Palladium(0) Nanoparticles: An In Situ Formed “Green and Recyclable" Catalyst for Suzuki-Miyaura Coupling in Water. ChemistrySelect 2016, 1, 4645-4651. [CrossRef]

31. Camp, J.E.; Dunsford, J.J.; Dacosta, O.S.G.; Blundell, R.K.; Adams, J.; Britton, J.; Smith, R.J.; Bousfield, T.W.; Fay, M.W. Recyclable glucose-derived palladium(0) nanoparticles as in situ-formed catalysts for cross-coupling reactions in aqueous media. RSC Adv. 2016, 6, 16115-16121. [CrossRef]

32. Qazi, F.; Hussain, Z.; Tahir, M.N. Advances in biogenic synthesis of palladium nanoparticles. RSC Adv. 2016, 6, 60277-60286. [CrossRef]

33. Anila, P.A.; Keerthiga, B.; Ramesh, M.; Muralisankar, T. Synthesis and characterization of palladium nanoparticles by chemical and green methods: A comparative study on hepatic toxicity using zebrafish as an animal model. Comp. Biochem. Phys. C 2021, 244, 108979. [CrossRef]

34. Zhang, D.; Ma, X.L.; Gu, Y.; Huang, H.; Zhang, G.W. Green Synthesis of Metallic Nanoparticles and Their Potential Applications to Treat Cancer. Front. Chem. 2020, 8, 799. [CrossRef] [PubMed]

35. Singh, A.; Gautam, P.K.; Verma, A.; Singh, V.; Shivapriya, P.M.; Shivalkar, S.; Sahoo, A.K.; Samanta, S.K. Green synthesis of metallic nanoparticles as effective alternatives to treat antibiotics resistant bacterial infections: A review. Biotechnol. Rep. 2020, 25, e00427. [CrossRef] [PubMed]

36. Yaqoob, S.B.; Adnan, R.; Rameez Khan, R.M.; Rashid, M. Gold, Silver, and Palladium Nanoparticles: A Chemical Tool for Biomedical Applications. Front. Chem. 2020, 8, 376. [CrossRef] [PubMed]

37. Fahmy, S.A.; Fawzy, I.M.; Saleh, B.M.; Issa, M.Y.; Bakowsky, U.; Azzazy, H.M.E.S. Green synthesis of platinum and palladium nanoparticles using Peganum harmala L. Seed alkaloids: Biological and computational studies. Nanomaterials 2021, $11,965$. [CrossRef]

38. Gulbagca, F.; Aygün, A.; Gülcan, M.; Ozdemir, S.; Gonca, S.; Şen, F. Green synthesis of palladium nanoparticles: Preparation, characterization, and investigation of antioxidant, antimicrobial, anticancer, and DNA cleavage activities. Appl. Organomet. Chem. 2021, 35, e6272. [CrossRef]

39. Sonbol, H.; Ameen, F.; AlYahya, S.; Almansob, A.; Alwakeel, S. Padina boryana mediated green synthesis of crystalline palladium nanoparticles as potential nanodrug against multidrug resistant bacteria and cancer cells. Sci. Rep. 2021, 11, 5444. [CrossRef]

40. Kirubaharan, C.J.; Fang, Z.; Sha, C.; Yong, Y.C. Green synthesis of Ag and Pd nanoparticles for water pollutants treatment. Water Sci. Technol. 2020, 82, 2344-2352. [CrossRef]

41. Azizi, S.; Shahri, M.M.; Rahman, H.S.; Rahim, R.A.; Rasedee, A.; Mohamad, R. Green synthesis palladium nanoparticles mediated by white tea (Camellia sinensis) extract with antioxidant, antibacterial, and antiproliferative activities toward the human leukemia (MOLT-4) cell line. Int. J. Nanomed. 2017, 12, 8841-8853. [CrossRef]

42. Surendra, T.V.; Roopan, S.M.; Arasu, M.V.; Al-Dhabi, N.A.; Rayalu, G. MRSM optimized Moringa oleifera peel extract for green synthesis of M. oleifera capped palladium nanoparticles with antibacterial and hemolytic property. J. Photochem. Photobiol. B Biol. 2016, 162, 550-557. [CrossRef]

43. Kora, A.J. Plant Arabinogalactan Gum Synthesized Palladium Nanoparticles: Characterization and Properties. J. Inorg. Organomet. Polym. Mater. 2019, 29, 2054-2063. [CrossRef]

44. Arsiya, F.; Sayadi, M.H.; Sobhani, S. Green synthesis of palladium nanoparticles using Chlorella vulgaris. Mater. Lett. 2017, 186, 113-115. [CrossRef]

45. Singh, J.; Dutta, T.; Kim, K.H.; Rawat, M.; Samddar, P.; Kumar, P. “Green” synthesis of metals and their oxide nanoparticles: Applications for environmental remediation. J. Nanobiotechnol. 2018, 16, 84. [CrossRef] 
46. Hegde, R.V.; Ghosh, A.; Jadhav, A.H.; Nizam, A.; Patil, S.A.; Peter, F.; Dateer, R.B. Biogenic synthesis of Pd-nanoparticles using Areca Nut Husk Extract: A greener approach to access $\alpha$-keto imides and stilbenes. New J. Chem. 2021, 45, 16213-16222. [CrossRef]

47. Bathula, C.K.S.; Kumar, K.A.; Yadav, H.; Ramesh, S.; Shinde, S.; Shrestha, N.K.; Mallikarjuna, K.; Kim, H. Ultrasonically driven green synthesis of palladium nanoparticles by Coleus amboinicus for catalytic reduction and Suzuki-Miyaura reaction. Colloids Surfaces B 2020, 192, 111026. [CrossRef]

48. Rabiee, N.; Bagherzadeh, M.; Kiani, M.; Ghadiri, A.M. Rosmarinus officinalis directed palladium nanoparticle synthesis: Investigation of potential anti-bacterial, anti-fungal and Mizoroki-Heck catalytic activities. Adv. Powder Technol. 2020, 31, 1402-1411. [CrossRef]

49. Kadam, J.; Madiwale, S.; Bashte, B.; Dindorkar, S.; Dhawal, P.; More, P. Green mediated synthesis of palladium nanoparticles using aqueous leaf extract of Gymnema sylvestre for catalytic reduction of Cr (VI). SN Appl. Sci. 2020, 2, 1854. [CrossRef]

50. Arde, S.M.; Rashinkar, G.S.; Jadhav, S.N.; Patil, A.D.; Salunkhe, R.S. Biogenic synthesis of palladium nanoparticles using Boswellia sarrata and their applications in cross-coupling reactions. Appl. Organomet. Chem. 2020, 34, e6012. [CrossRef]

51. Ün, Ş.Ş.; Ünlü, A.; Ün, İ.; Ok, S. Green synthesis, characterization and catalytic activity evaluation of palladium nanoparticles facilitated by Punica granatum peel extract. Inorg. Nano-Met. Chem. 2021, 51, 1232-1240. [CrossRef]

52. Shahri, M.M. Highly efficient of cross-coupling reaction supported green synthesized palladium nanoparticles coated natural ligands as heterogeneous reusable nanocatalyst. J. Nanostruct. 2019, 9, 669-678. [CrossRef]

53. Sarmah, M.; Neog, A.B.; Boruah, P.K.; Das, M.R.; Bharali, P.; Bora, U. Effect of Substrates on Catalytic Activity of Biogenic Palladium Nanoparticles in C-C Cross-Coupling Reactions. ACS Omega 2019, 4, 3329-3340. [CrossRef]

54. Gaikwad, D.S.; Undale, K.A.; Kalel, R.A.; Patil, D.B. Acacia concinna pods: A natural and new bioreductant for palladium nanoparticles and its application to Suzuki-Miyaura coupling. J. Iran. Chem. Soc. 2019, 16, 2135-2141. [CrossRef]

55. Phukan, S.; Mahanta, A.; Kakati, D.; Rashid, M.H. Green chemical synthesis of Pd nanoparticles for use as efficient catalyst in Suzuki-Miyaura cross-coupling reaction. Appl. Organomet. Chem. 2019, 33, e4758. [CrossRef]

56. Garole, V.J.; Choudhary, B.C.; Tetgure, S.R.; Garole, D.J.; Borse, A.U. Palladium nanocatalyst: Green synthesis, characterization, and catalytic application. Int. J. Environ. Sci. Technol. 2019, 16, 7885-7892. [CrossRef]

57. Garai, C.; Hasan, S.N.; Barai, A.C.; Ghorai, S.; Panja, S.K.; Bag, B.G. Green synthesis of Terminalia arjuna-conjugated palladium nanoparticles (TA-PdNPs) and its catalytic applications. J. Nanostructure Chem. 2018, 8, 465-472. [CrossRef]

58. Dewan, A.; Sarmah, M.; Thakur, A.J.; Bharali, P.; Bora, U. Greener Biogenic Approach for the Synthesis of Palladium Nanoparticles Using Papaya Peel: An Eco-Friendly Catalyst for C-C Coupling Reaction. ACS Omega 2018, 3, 5327-5335. [CrossRef]

59. Kandathil, V.; Dateer, R.B.; Sasidhar, B.S.; Patil, S.A.; Patil, S.A. Green Synthesis of Palladium Nanoparticles: Applications in Aryl Halide Cyanation and Hiyama Cross-Coupling Reaction under Ligand Free Conditions. Catal. Lett. 2018, 148, 1562-1578. [CrossRef]

60. Tanreh, S.; Hallajian, S.; Hamedani, Y.P.; Nazari, P.; Darvishi, K.; Hekmati, M. Green Synthesis of Pd Nanoparticles Mediated by Thymbra Spicata Leaves Extract and Its Application as a Recyclable Nanocatalyst for Reduction of 4-Nitrophenol and Suzuki Reactions. J. Inorg. Organomet. Polym. Mater. 2018, 28, 1001-1010. [CrossRef]

61. Veisi, H.; Adib, M.; Karimi-Nami, R.; Yasaei, Z.; Tajik, M.; Mosavat, T.S.; Hemmati, S. Suzuki-Miyaura coupling catalyzed by palladium nanoparticles biosynthesized using Glycyrrhiza glabra as reducing and stabilyzing agent. Appl. Organomet. Chem. 2018, 32, e4138. [CrossRef]

62. Ahmadi, F.; Hekmati, M.; Yousefi, M.; Veisi, H. Biogenic synthesis of Palladium nanoparticles mediated by Artemisia abrotanumaqueous extract and its catalytic evaluation for Suzuki coupling reactions. Asian J. Nanosci. Mater. 2018, 1, 104-114. [CrossRef]

63. Lebaschi, S.; Hekmati, M.; Veisi, H. Green synthesis of palladium nanoparticles mediated by black tea leaves (Camellia sinensis) extract: Catalytic activity in the reduction of 4-nitrophenol and Suzuki-Miyaura coupling reaction under ligand-free conditions. J. Colloid Interface Sci. 2017, 485, 223-231. [CrossRef]

64. Narasaiah, P.; Kumar Mandal, B.; Sarada, N.C. Green synthesis of Pd NPs from Pimpinella tirupatiensis plant extract and their application in photocatalytic activity dye degradation. IOP Conf. Ser. Mater. Sci. Eng. 2017, 263, 022013. [CrossRef]

65. Rafi Shaik, M.; Ali, Z.J.Q.; Khan, M.; Kuniyil, M.; Assal, M.E.; Alkhathlan, H.Z.; Al-Warthan, A.; Siddiqui, M.R.H.; Khan, M.; Adil, S.F. Green synthesis and characterization of palladium nanoparticles using Origanum vulgare L. extract and their catalytic activity. Molecules 2017, 22, 165. [CrossRef] [PubMed]

66. Majumdar, R.; Tantayanon, S.; Bag, B.G. Synthesis of palladium nanoparticles with leaf extract of Chrysophyllum cainito (Star apple) and their applications as efficient catalyst for C-C coupling and reduction reactions. Int. Nano Lett. 2017, 7, 267-274. [CrossRef]

67. Mallikarjuna, K.; Bathula, C.; Buruga, K.; Shrestha, N.K.; Noh, Y.Y.; Kim, H. Green synthesis of palladium nanoparticles using fenugreek tea and their catalytic applications in organic reactions. Mater. Lett. 2017, 205, 138-141. [CrossRef]

68. Khan, M.; Albalawi, G.H.; Shaik, M.R.; Khan, M.; Adil, S.F.; Kuniyil, M.; Alkhathlan, H.Z.; Al-Warthan, A.; Siddiqui, M.R.H. Miswak mediated green synthesized palladium nanoparticles as effective catalysts for the Suzuki coupling reactions in aqueous media. J. Saudi Chem. Soc. 2017, 21, 450-457. [CrossRef]

69. Borah, R.K.; Mahanta, A.; Dutta, A.; Bora, U.; Thakur, A.J. A green synthesis of palladium nanoparticles by Sapindus mukorossi seed extract and use in efficient room temperature Suzuki-Miyaura cross-coupling reaction. Appl. Organomet. Chem. 2017, 31, e3784. [CrossRef] 
70. Hekmati, M.; Bonyasi, F.; Javaheri, H.; Hemmati, S. Green synthesis of palladium nanoparticles using Hibiscus sabdariffa L. flower extract: Heterogeneous and reusable nanocatalyst in Suzuki coupling reactions. Appl. Organomet. Chem. 2017, 31 , e3757. [CrossRef]

71. Veisi, H.; Rostami, A.; Shirinbayan, M. Greener approach for synthesis of monodispersed palladium nanoparticles using aqueous extract of green tea and their catalytic activity for the Suzuki-Miyaura coupling reaction and the reduction of nitroarenes. Appl. Organomet. Chem. 2017, 31, e3609. [CrossRef]

72. Liu, G.; Bai, X. Biosynthesis of palladium nanoparticles using Poplar leaf extract and its application in Suzuki coupling reaction. IET Nanobiotech. 2017, 11, 310-316. [CrossRef]

73. Nasrollahzadeh, M.; Mohammad Sajadi, S. Pd nanoparticles synthesized in situ with the use of Euphorbia granulate leaf extract: Catalytic properties of the resulting particles. J. Colloid Interface Sci. 2016, 462, 243-251. [CrossRef]

74. Veisi, H.; Rashtiani, A.; Barjasteh, V. Biosynthesis of palladium nanoparticles using Rosa canina fruit extract and their use as a heterogeneous and recyclable catalyst for Suzuki-Miyaura coupling reactions in water. Appl. Organomet. Chem. 2016, 30, 231-235. [CrossRef]

75. Nasrollahzadeh, M.; Sajadi, S.M.; Maham, M. Green synthesis of palladium nanoparticles using Hippophae rhamnoides Linn leaf extract and their catalytic activity for the Suzuki-Miyaura coupling in water. J. Mol. Catal. A Chem. 2015, 396, 297-303. [CrossRef]

76. Veisi, H.; Ghorbani-Vaghei, R.; Hemmati, S.; Haji Aliani, M.; Ozturk, T. Green and effective route for the synthesis of monodispersed palladium nanoparticles using herbal tea extract (Stachys lavandulifolia) as reductant, stabilizer and capping agent, and their application as homogeneous and reusable catalyst in Suzuki coupling reactions in water. Appl. Organomet. Chem. 2015, 29, 26-32. [CrossRef]

77. Nasrollahzadeh, M.; Sajadi, S.M.; Maham, M.; Ehsani, A. Facile and surfactant-free synthesis of Pd nanoparticles by the extract of the fruits of Piper longum and their catalytic performance for the Sonogashira coupling reaction in water under ligand- and copper-free conditions. RSC Adv. 2015, 5, 2562-2567. [CrossRef]

78. Nasrollahzadeh, M.; Sajadi, S.M.; Honarmand, E.; Maham, M. Preparation of palladium nanoparticles using Euphorbia thymifolia L. leaf extract and evaluation of catalytic activity in the ligand-free Stille and Hiyama cross-coupling reactions in water. New J. Chem. 2015, 39, 4745-4752. [CrossRef]

79. Lakshmipathy, R.; Palakshi Reddy, B.; Sarada, N.C.; Chidambaram, K.; Khadeer Pasha, S. Watermelon rind-mediated green synthesis of noble palladium nanoparticles: Catalytic application. Appl. Nanosci. 2015, 5, 223-228. [CrossRef]

80. Veisi, H.; Karmakar, B.; Tamoradi, T.; Tayebee, R.; Sajjadifar, S.; Lotfi, S.; Maleki, B.; Hemmati, S. Bio-inspired synthesis of palladium nanoparticles fabricated magnetic $\mathrm{Fe}_{3} \mathrm{O}_{4}$ nanocomposite over Fritillaria imperialis flower extract as an efficient recyclable catalyst for the reduction of nitroarenes. Sci. Rep. 2021, 11, 4515. [CrossRef]

81. Hemmati, S.; Yousefi, M.; Salehi, M.H.; Amiri, M.; Hekmati, M. Palladium nanoparticles immobilized over Strawberry fruit extract coated $\mathrm{Fe}_{3} \mathrm{O}_{4}$ NPs: A magnetic reusable nanocatalyst for Suzuki-Miyaura coupling reactions. Appl. Organomet. Chem. 2020, 34, e5653. [CrossRef]

82. Veisi, H.; Pirhayati, M.; Kakanejadifard, A.; Mohammadi, P.; Abdi, M.R.; Gholami, J.; Hemmati, S. In Situ Green Synthesis of Pd Nanoparticles on Tannic Acid-Modified Magnetite Nanoparticles as a Green Reductant and Stabilizer Agent: Its Application as a Recyclable Nanocatalyst $\left(\mathrm{Fe}_{3} \mathrm{O}_{4} @ \mathrm{TA} / \mathrm{Pd}\right)$ for Reduction of 4-Nitrophenol and Suzuki Reactions. ChemistrySelect 2018, 3 , 1820-1826. [CrossRef]

83. Nasrollahzadeh, M.; Sajadi, S.M.; Rostami-Vartooni, A.; Khalaj, M. Green synthesis of Pd/Fe $\mathrm{O}_{4}$ nanoparticles using Euphorbia condylocarpa M. bieb root extract and their catalytic applications as magnetically recoverable and stable recyclable catalysts for the phosphine-free Sonogashira and Suzuki coupling reactions. J. Mol. Catal A Chem. 2015, 396, 31-39. [CrossRef]

84. Mallikarjuna, K.; Reddy, L.V.; Al-Rasheed, S.; Mohammed, A.; Gedi, S.; Kim, W.K. Green synthesis of reduced graphene oxidesupported palladium nanoparticles by Coleus amboinicus and its enhanced catalytic efficiency and antibacterial activity. Crystals 2021, 11, 134. [CrossRef]

85. Salehi, M.H.; Yousefi, M.; Hekmati, M.; Balali, E. In Situ biosynthesis of palladium nanoparticles on Artemisia abrotanum extract-modified graphene oxide and its catalytic activity for Suzuki coupling reactions. Polyhedron 2019, 165, 132-137. [CrossRef]

86. Pathak, C.; Borah, G. Green synthesis of Pd@rGO nanocomposite using Piper (Piper nigrum) leaf extract and its catalytic activity towards alcohol oxidation in water at room temperature. Mater. Res. Express 2019, 6, 1250i1. [CrossRef]

87. Veisi, H.; Tamoradi, T.; Karmakar, B.; Mohammadi, P.; Hemmati, S. In Situ biogenic synthesis of Pd nanoparticles over reduced graphene oxide by using a plant extract (Thymbra spicata) and its catalytic evaluation towards cyanation of aryl halides. Mater. Sci. Eng. C 2019, 104, 109919. [CrossRef]

88. Khan, M.; Kuniyil, M.; Shaik, M.R.; Khan, M.; Adil, S.F.; Al-Warthan, A.; Alkhathlan, H.Z.; Tremel, W.; Tahir, M.N.; Siddiqui, M.R.H. Plant extract mediated eco-friendly synthesis of pd@graphene nanocatalyst: An efficient and reusable catalyst for the Suzuki-Miyaura coupling. Catalysts 2017, 7, 20. [CrossRef]

89. Seyedi, N.; Saidi, K.; Sheibani, H. Green Synthesis of Pd Nanoparticles Supported on Magnetic Graphene Oxide by Origanum vulgare Leaf Plant Extract: Catalytic Activity in the Reduction of Organic Dyes and Suzuki-Miyaura Cross-Coupling Reaction. Catal. Lett. 2018, 148, 277-288. [CrossRef]

90. Lin, Y.C.; Chen, C.H.; Chen, K.S.; Peng, Y.P.; Lin, Y.C.; Huang, S.W.; Huang, C.E.; Lai, H.W.; Li, H.W. Green synthesized palladium coated titanium nanotube arrays for simultaneous azo-dye degradation and hydrogen production. Catalysts 2020, 10, 1330. [CrossRef] 
91. Nasrollahzadeh, M.; Sajadi, S. M Green synthesis, characterization and catalytic activity of the Pd/TiO2 nanoparticles for the ligand-free Suzuki-Miyaura coupling reaction. J. Colloid Interface Sci. 2016, 465, 121-127. [CrossRef]

92. Nasrollahzadeh, M.; Sajadi, S.M.; Rostami-Vartooni, A.; Bagherzadeh, M. Green synthesis of Pd/CuO nanoparticles by Theobroma cacao L. seeds extract and their catalytic performance for the reduction of 4-nitrophenol and phosphine-free Heck coupling reaction under aerobic conditions. J. Colloid Interface Sci. 2015, 448, 106-113. [CrossRef]

93. Manjare, S.B.; Chaudhari, R.A. Environment-friendly synthesis of palladium nanoparticles loaded on Zeolite Type-Y (Na-form) using Anacardium Occidentale shell extract (Cashew nut shell extract), characterization and application in -C-C- coupling reaction. J. Environ. Chem. Eng. 2020, 8, 104213. [CrossRef]

94. Liu, G.H.; Bai, X. FGreen synthesis of Pd nanoparticles supported on LDHs and its application in the Suzuki coupling reaction. IOP Conf. Ser. Mater. Sci. and Eng. 2018, 292, 012027. [CrossRef]

95. Gogoi, N.; Bordoloi, P.; Borah, G.; Gogoi, P.K. Synthesis of Palladium Nanoparticle by Bio-reduction Method and Its Effectiveness as Heterogeneous Catalyst Towards Selective Oxidation of Benzyl Alcohols in Aqueous Media. Catal. Lett. 2017, 147, 539-546. [CrossRef]

96. Saikia, P.K.; Bhattacharjee, R.P.; Sarmah, P.P.; Saikia, L.; Dutta, D.K. A green synthesis of Pd nanoparticles supported on modified montmorillonite using aqueous: Ocimum sanctum leaf extract: A sustainable catalyst for hydrodechlorination of 4-chlorophenol. RSC Adv. 2016, 6, 110011-110018. [CrossRef]

97. Khazaei, M.; Khazaei, A.; Nasrollahzadeh, M.; Tahsili, M.R. Highly efficient reusable Pd nanoparticles based on eggshell: Green synthesis, characterization and their application in catalytic reduction of variety of organic dyes and ligand-free oxidative hydroxylation of phenylboronic acid at room temperature. Tetrahedron 2017, 73, 5613-5623. [CrossRef]

98. Borah, R.K.; Saikia, H.J.; Mahanta, A.; Das, V.K.; Bora, U.; Thakur, A.J. Biosynthesis of poly(ethylene glycol)-supported palladium nanoparticles using Colocasia esculenta leaf extract and their catalytic activity for Suzuki-Miyaura cross-coupling reactions. RSC Adv. 2015, 5, 72453-72457. [CrossRef]

99. Wang, D.; Astruc, D. Fast-growing field of magnetically recyclable nanocatalysts. Chem. Rev. 2014, 114, 6949-6985. [CrossRef]

100. Díaz-Sánchez, M.; Díaz-García, D.; Prashar, S.; Gómez-Ruiz, S. Palladium nanoparticles supported on silica, alumina or Titania: Greener alternatives for Suzuki-Miyaura and other C-C coupling reactions. Environ. Chem. Lett. 2019, 17, 1585-1602. [CrossRef]

101. Veerakumar, P.; Thanasekaran, P.; Lu, K.L.; Liu, S.B.; Rajagopal, S. Functionalized Silica Matrices and Palladium: A Versatile Heterogeneous Catalyst for Suzuki, Heck, and Sonogashira Reactions. ACS Sust. Chem. Eng. 2017, 5, 6357-6376. [CrossRef]

102. Veerakumar, P.; Lin, K.C. An overview of palladium supported on carbon-based materials: Synthesis, characterization, and its catalytic activity for reduction of hexavalent chromium. Chemosphere 2020, 253, 126750. [CrossRef]

103. Gholinejad, M.; Naghshbandi, Z.; Nájera, C. Carbon-Derived Supports for Palladium Nanoparticles as Catalysts for CarbonCarbon Bonds Formation. ChemCatChem 2019, 11, 1792-1823. [CrossRef]

104. Tao, R.; Ma, X.; Wei, X.; Jin, Y.; Qiu, L.; Zhang, W. Porous organic polymer material supported palladium nanoparticles. J. Mater. Chem. A 2020, 8, 17360-17391. [CrossRef]

105. Ahmad, H. Celluloses as Green Support of Palladium Nanoparticles for Application in Heterogeneous Catalysis: A Brief Review. J. Cluster Sci. 2021. [CrossRef]

106. Wolfson, A.; Levy-Ontman, O. Development and application of palladium nanoparticles on renewable polysaccharides as catalysts for the Suzuki cross-coupling of halobenzenes and phenylboronic acids. Mol. Catal. 2020, 493, 111048. [CrossRef]

107. Aabaka, S.R.; Mao, J.; Lavanya, M.; Venkateswarlu, K.; Huang, Z.; Mao, J.; Yang, X.; Lin, C. Nanocellulose Supported PdNPs as in situ Formed Nano Catalyst for the Suzuki Coupling Reaction in Aqueous Media: A Green Approach and Waste to Wealth. J. Organomet. Chem. 2021, 937, 121719. [CrossRef]

108. Le, V.D.; Le, T.C.H.; Chau, V.T.; Le, T.N.D.; Dang, C.H.; Vo, T.T.N.; Nguyen, T.D.; Nguyen, T.D. Palladium nanoparticles in situ synthesized on Cyclea barbata pectin as a heterogeneous catalyst for Heck coupling in water, the reduction of nitrophenols and alkynes. New J. Chem. 2021, 45, 4746-4755. [CrossRef]

109. Kempasiddaiah, M.; Kandathil, V.; Dateer, R.B.; Sasidhar, B.S.; Patil, S.A.; Patil, S.A. Immobilizing biogenically synthesized palladium nanoparticles on cellulose support as a green and sustainable dip catalyst for cross-coupling reaction. Cellulose 2020, 27, 3335-3357. [CrossRef]

110. Kempasiddaiah, M.; Kandathil, V.; Dateer, R.B.; Sasidhar, B.S.; Patil, S.A.; Patil, S.A. Palladium-catalyzed denitrogenative cross-coupling of aryl halides with arylhydrazines under mild reaction conditions. Transit. Met. Chem. 2021, 46, $273-281$. [CrossRef]

111. Shahbazi, E.; Bahrami, K. Palladium Nanoparticles Doped on the Chitosan Nanofibers Modified with 2-Aminobenzaldehyde as a Nanocatalyst in Cross-Coupling Reactions. ChemistrySelect 2020, 5, 5489-5496. [CrossRef]

112. Easson, M.W.; Jordan, J.H.; Bland, J.M.; Hinchliffe, D.J.; Condon, B.D. Application of Brown Cotton-Supported Palladium Nanoparticles in Suzuki-Miyaura Cross-Coupling Reactions. ACS Appl. Nano Mater. 2020, 3, 6304-6309. [CrossRef]

113. Wang, Z.; Bai, X. One-pot synthesis of bio-supported Pd nanoparticles by using clove leaf and their catalytic performance for Suzuki coupling reaction. J. Mol. Struct. 2020, 1219, 128538. [CrossRef]

114. Baran, T.; Nasrollahzadeh, M. Cyanation of aryl halides and Suzuki-Miyaura coupling reaction using palladium nanoparticles anchored on developed biodegradable microbeads. Int. J. Biol. Macromol. 2020, 148, 565-573. [CrossRef] [PubMed] 
115. Huang, P.; Zeng, X.; Du, F.; Zhang, L.; Peng, X. Palladium Nanoparticles Anchored on Thiol Functionalized Xylose Hydrochar Microspheres: An Efficient Heterogeneous Catalyst for Suzuki Cross-Coupling Reactions. Catal. Lett. 2020, 150, 1011-1019. [CrossRef]

116. Mosleh, I.; Shahsavari, H.R.; Beitle, R.; Beyzavi, M.H. Recombinant Peptide Fusion Protein-Templated Palladium Nanoparticles for Suzuki-Miyaura and Stille Coupling Reactions. ChemCatChem 2020, 12, 2942-2946. [CrossRef]

117. Bendre, A.D.; Patil, V.P.; Terdale, S.S.; Kodam, K.M.; Waghmode, S.B. A simple, efficient and green approach for the synthesis of palladium nanoparticles using Oxytocin: Application for ligand free Suzuki reaction and total synthesis of aspongpyrazine A. J. Organomet. Chem. 2020, 909, 121093. [CrossRef]

118. Rashidi, M.; Islami, M.R.; Tikdari, A.M. Green synthesis of Pd nanoparticles supported on modified Nonpareil almond shell using almond hull extract: A beneficial nanocatalyst for convenient reduction of organic dyes. J. Mater. Sci. Mater. Electron. 2019, 30, 18111-18122. [CrossRef]

119. Kalanthoden, A.N.; Shaikh, M.N.; Aziz, M.A.; Rani, S.K. Pd Nanoparticles Decorated on Jute Sticks: Dip-Catalyst of SuzukiMiyaura and Mizoroki-Heck C-C Bond Formation Reactions in Water. ChemistrySelect 2019, 4, 12832-12840. [CrossRef]

120. Shaikh, M.N. Pd nanoparticles on green support as dip-catalyst: A facile transfer hydrogenation of olefins and: $\mathrm{N}$-heteroarenes in water. RSC Adv. 2019, 9, 28199-28206. [CrossRef]

121. Han, Z.; Dong, L.; Zhang, J.; Cui, T.; Chen, S.; Ma, G.; Guo, X.; Wang, L. Green synthesis of palladium nanoparticles using lentinan for catalytic activity and biological applications. RSC Adv. 2019, 9, 38265-38270. [CrossRef]

122. Dolatkhah, Z.; Javanshir, S.; Bazgir, A. Isinglass-palladium as collagen peptide-metal complex: A highly efficient heterogeneous biocatalyst for Suzuki cross-coupling reaction in water. J. Iran. Chem. Soc. 2019, 16, 1473-1481. [CrossRef]

123. Marulasiddeshwara, M.B.; Kumar, P.R. Phosphine and Copper-free Sonogashira coupling reaction catalyzed by lignin supported palladium nanoparticles. Mater. Today Proc. 2018, 5, 20811-20818. [CrossRef]

124. Kora, A.J.; Rastogi, L. Green synthesis of palladium nanoparticles using gum ghatti (Anogeissus latifolia) and its application as an antioxidant and catalyst. Arab. J. Chem. 2018, 11, 1097-1106. [CrossRef]

125. Baran, T. Ultrasound-accelerated synthesis of biphenyl compounds using novel $\mathrm{Pd}(0)$ nanoparticles immobilized on bio-composite. Ultrason. Sonochem. 2018, 45, 231-237. [CrossRef]

126. Baran, N.Y.; Baran, T.; Menteş, A. Production of novel palladium nanocatalyst stabilized with sustainable chitosan/cellulose composite and its catalytic performance in Suzuki-Miyaura coupling reactions. Carbohydr. Polym. 2018, 181, 596-604. [CrossRef]

127. Baran, T.; Baran, N.Y.; Menteş, A. Sustainable chitosan/starch composite material for stabilization of palladium nanoparticles: Synthesis, characterization and investigation of catalytic behaviour of Pd@chitosan/starch nanocomposite in Suzuki-Miyaura reaction. Appl. Organomet. Chem. 2018, 32, e4075. [CrossRef]

128. Liu, G.; Bai, X.; Lv, H. Biosynthesis of supported Pd nanoparticles using poplar leaf as a reducing agent and carrier: A green route to highly efficient and reusable Suzuki coupling reaction catalyst. Inorg. Nano-Met. Chem. 2017, 47, 1226-1233. [CrossRef]

129. Rahmati, S.; Arabi, A.; Khazaei, A.; Khazaei, M. In Situ stabilization of $\operatorname{Pd}(0)$ nanoparticles into a mixture of natural carbohydrate beads: A novel and highly efficient heterogeneous catalyst system for Heck coupling reactions. Appl. Organomet. Chem. 2017, 31, e3588. [CrossRef]

130. Liu, G.; Bai, X.; Lv, H. Green synthesis of supported palladium nanoparticles employing pine needles as reducing agent and carrier: New reusable heterogeneous catalyst in the Suzuki coupling reaction. Appl. Organomet. Chem. 2017, 31, e3587. [CrossRef]

131. Majumdar, R.; Tantayanon, S.; Gopal Bag, B. A Novel Trihybrid Material Based on Renewables: An Efficient Recyclable Heterogeneous Catalyst for C-C Coupling and Reduction Reactions. Chem. Asian J. 2016, 11, 2406-2414. [CrossRef]

132. Veisi, H.; Nasrabadi, N.H.; Mohammadi, P. Biosynthesis of palladium nanoparticles as a heterogeneous and reusable nanocatalyst for reduction of nitroarenes and Suzuki coupling reactions. Appl. Organomet. Chem. 2016, 30, 890-896. [CrossRef]

133. Wu, C.; Peng, X.; Zhong, L.; Li, X.; Sun, R. Green synthesis of palladium nanoparticles via branched polymers: A bio-based nanocomposite for C-C coupling reactions. RSC Adv. 2016, 6, 32202-32211. [CrossRef]

134. Frindy, S.; Primo, A.; Lahcini, M.; Bousmina, M.; Garcia, H.; El Kadib, A. Pd embedded in chitosan microspheres as tunable soft-materials for Sonogashira cross-coupling in water-ethanol mixture. Green Chem. 2015, 17, 1893-1898. [CrossRef]

135. Baruah, D.; Das, R.N.; Hazarika, S.; Konwar, D. Biogenic synthesis of cellulose supported Pd(0) nanoparticles using hearth wood extract of Artocarpus lakoocha Roxb-A green, efficient and versatile catalyst for Suzuki and Heck coupling in water under microwave heating. Catal. Commun. 2015, 72, 73-80. [CrossRef]

136. Veisi, H.; Faraji, A.R.; Hemmati, S.; Gil, A. Green synthesis of palladium nanoparticles using Pistacia atlantica kurdica gum and their catalytic performance in Mizoroki-Heck and Suzuki-Miyaura coupling reactions in aqueous solutions. Appl. Organomet. Chem. 2015, 29, 517-523. [CrossRef]

137. Affrose, A.; Suresh, P.; Azath, I.A.; Pitchumani, K. Palladium nanoparticles embedded on thiourea-modified chitosan: A green and sustainable heterogeneous catalyst for the Suzuki reaction in water. RSC Adv. 2015, 5, 27533-27539. [CrossRef]

138. Khazaei, A.; Khazaei, M.; Rahmati, S. A green method for the synthesis of gelatin/pectin stabilized palladium nano-particles as efficient heterogeneous catalyst for solvent-free Mizoroki-Heck reaction. J. Mol. Catal. A Chem. 2015, 398, 241-247. [CrossRef]

139. Camacho, A.S.; Martín-García, I.; Contreras-Celedón, C.; Chacón-García, L.; Alonso, F. DNA-supported palladium nanoparticles as a reusable catalyst for the copper- and ligand-free Sonogashira reaction. Catal. Sci. Technol. 2017, 7, 2262-2273. [CrossRef]

140. Huang, J.; Lin, L.; Sun, D.; Chen, H.; Yang, D.; Li, Q. Bio-inspired synthesis of metal nanomaterials and applications. Chem. Soci. Rev. 2015, 44, 6330-6374. [CrossRef] 
141. Tan, L.H.; Xing, H.; Lu, Y. DNA as a powerful tool for morphology control, spatial positioning, and dynamic assembly of nanoparticles. Acc. Chem. Res. 2014, 47, 1881-1890. [CrossRef]

142. Veisi, H.; Joshani, Z.; Karmakar, B.; Tamoradi, T.; Heravi, M.M.; Gholami, J. Ultrasound assisted synthesis of Pd NPs decorated chitosan-starch functionalized $\mathrm{Fe}_{3} \mathrm{O}_{4}$ nanocomposite catalyst towards Suzuki-Miyaura coupling and reduction of 4-nitrophenol. Int. J. Biol. Macromol. 2021, 172, 104-113. [CrossRef]

143. Hasan, K. Methyl Salicylate Functionalized Magnetic Chitosan Immobilized Palladium Nanoparticles: An Efficient Catalyst for the Suzuki and Heck Coupling Reactions in Water. ChemistrySelect 2020, 5, 7129-7140. [CrossRef]

144. Salamatmanesh, A.; Heydari, A.; Nahzomi, H.T. Stabilizing Pd on magnetic phosphine-functionalized cellulose: DFT study and catalytic performance under deep eutectic solvent assisted conditions. Carbohydr. Polym. 2020, 235, 115947. [CrossRef]

145. Bharamanagowda, M.M.; Panchangam, R.K. $\mathrm{Fe}_{3} \mathrm{O}_{4}$-Lignin@Pd-NPs: A highly efficient, magnetically recoverable and recyclable catalyst for Mizoroki-Heck reaction under solvent-free conditions. Appl. Organomet. Chem. 2020, 34, e5837. [CrossRef]

146. Baran, T.; Sargin, I. Green synthesis of a palladium nanocatalyst anchored on magnetic lignin-chitosan beads for synthesis of biaryls and aryl halide cyanation. Int. J. Biol. Macromol. 2020, 155, 814-822. [CrossRef]

147. Baran, T. Production and Application of Highly Efficient and Reusable Palladium Nanocatalyst Decorated on the Magnetically Retrievable Chitosan/Activated Carbon Composite Microcapsules. Catal. Lett. 2019, 49, 1496-1503. [CrossRef]

148. Baran, T.; Nasrollahzadeh, M. Facile synthesis of palladium nanoparticles immobilized on magnetic biodegradable microcapsules used as effective and recyclable catalyst in Suzuki-Miyaura reaction and p-nitrophenol reduction. Carbohydr. Polym. 2019, 222, 115029. [CrossRef]

149. Dolatkhah, Z.; Javanshir, S.; Bazgir, A.; Hemmati, B. Palladium on magnetic Irish moss: A new nano-biocatalyst for suzuki type cross-coupling reactions. Appl. Organomet. Chem. 2019, 33, e4859. [CrossRef]

150. Hajipour, A.R.; Tavangar-Rizi, Z. Palladium nanoparticles immobilized on magnetic methionine-functionalized chitosan: A versatile catalyst for Suzuki and copper-free Sonogashira reactions of aryl halides at room temperature in water as only solvent. Appl. Organomet. Chem. 2017, 31, e3701. [CrossRef]

151. Pourjavadi, A.; Motamedi, A.; Marvdashti, Z.; Hosseini, S.H. Magnetic nanocomposite based on functionalized salep as a green support for immobilization of palladium nanoparticles: Reusable heterogeneous catalyst for Suzuki coupling reactions. Catal. Commun. 2017, 97, 27-31. [CrossRef]

152. Naghipour, A.; Fakhri, A. Heterogeneous $\mathrm{Fe}_{3} \mathrm{O}_{4} @$ chitosan-Schiff base Pd nanocatalyst: Fabrication, characterization and application as highly efficient and magnetically-recoverable catalyst for Suzuki-Miyaura and Heck-Mizoroki C-C coupling reactions. Catal. Commun. 2016, 73, 39-45. [CrossRef]

153. Kandathil, V.; Kempasiddaiah, M.; Nataraj, S.K.; Somappa, S.B.; Patil, S.A. DNA as a bioligand supported on magnetite for grafting palladium nanoparticles for cross-coupling reaction. Appl. Organomet. Chem. 2020, 34, e5357. [CrossRef]

154. Çalışkan, M.; Baran, T. Decorated palladium nanoparticles on chitosan/ $\delta$-FeOOH microspheres: A highly active and recyclable catalyst for Suzuki coupling reaction and cyanation of aryl halides. Int. J. Biol. Macromol. 2021, 174, 120-133. [CrossRef] [PubMed]

155. Farzad, E.; Veisi, H. $\mathrm{Fe}_{3} \mathrm{O}_{4} / \mathrm{SiO}_{2}$ nanoparticles coated with polydopamine as a novel magnetite reductant and stabilizer sorbent for palladium ions: Synthetic application of $\mathrm{Fe}_{3} \mathrm{O}_{4} / \mathrm{SiO}_{2} @ \mathrm{PDA} / \mathrm{Pd}$ for reduction of 4-nitrophenol and Suzuki reactions. J. Ind. Eng. Chem. 2018, 60, 114-124. [CrossRef]

156. Kalanpour, N.; Nejati, S.; Keshipour, S. Pd nanoparticles/graphene quantum dot supported on chitosan as a new catalyst for the reduction of nitroarenes to arylamines. J. Iran. Chem. Soc. 2021, 18, 1243-1250. [CrossRef]

157. Putta, C.; Sharavath, V.; Sarkar, S.; Ghosh, S. Palladium nanoparticles on $\beta$-cyclodextrin functionalised graphene nanosheets: A supramolecular based heterogeneous catalyst for $\mathrm{C}-\mathrm{C}$ coupling reactions under green reaction conditions. RSC Adv. 2015, 5, 6652-6660. [CrossRef]

158. Sargin, I.; Baran, T.; Arslan, G. Environmental remediation by chitosan-carbon nanotube supported palladium nanoparticles: Conversion of toxic nitroarenes into aromatic amines, degradation of dye pollutants and green synthesis of biaryls. Sep. Purif. Technol. 2020, 247, 116987. [CrossRef]

159. Hajipour, A.R.; Khorsandi, Z. Efficient Suzuki and Sonogashira coupling reactions catalyzed by Pd/DNA@MWCNTs in green solvents under mild conditions. Nanochem. Res. 2019, 4, 132-139. [CrossRef]

160. Nasrollahzadeh, M.; Shafiei, N.; Baran, T.; Pakzad, K.; Tahsili, M.R.; Baran, N.Y.; Shokouhimehr, M. Facile synthesis of Pd nanoparticles supported on a novel Schiff base modified chitosan-kaolin: Antibacterial and catalytic activities in Sonogashira coupling reaction. J. Organomet. Chem. 2021, 945, 121849. [CrossRef]

161. Shafiei, N.; Nasrollahzadeh, M.; Baran, T.; Baran, N.Y.; Shokouhimehr, M. Pd nanoparticles loaded on modified chitosan-Unye bentonite microcapsules: A reusable nanocatalyst for Sonogashira coupling reaction. Carbohydr. Polym. 2021, 262, 117920. [CrossRef]

162. Zeng, M.; Yuan, X.; Zuo, S.; Qi, C. Novel chitosan-based/montmorillonite/palladium hybrid microspheres as heterogeneous catalyst for Sonogashira reactions. RSC Adv. 2015, 5, 37995-38000. [CrossRef]

163. Valentini, F.; Ferlin, F.; Lilli, S.; Marrocchi, A.; Ping, L.; Gu, Y.; Vaccaro, L. Valorisation of urban waste to access low-cost heterogeneous palladium catalysts for cross-coupling reactions in biomass-derived $\gamma$-valerolactone. Green Chem. 2021, 23, 5887-5895. [CrossRef]

164. Moradi, P.; Hajjami, M.; Valizadeh-Kakhki, F. Biochar as heterogeneous support for immobilization of Pd as efficient and reusable biocatalyst in C-C coupling reactions. Appl. Organomet. Chem. 2019, 33, e5205. [CrossRef] 
165. Enneiymy, M.; Le Drian, C.; Ghimbeu, C.M.; Becht, J.M. Mesoporous carbon supported ultrasmall palladium particles as highly active catalyst for Suzuki-Miyaura reaction. Appl. Organomet. Chem. 2019, 33, e5104. [CrossRef]

166. Patel, A.R.; Asatkar, A.; Patel, G.; Banerjee, S. Synthesis of Rice Husk Derived Activated Mesoporous Carbon Immobilized Palladium Hybrid Nano-Catalyst for Ligand-Free Mizoroki-Heck/Suzuki/Sonogashira Cross-Coupling Reactions. ChemistrySelect 2019, 4, 5577-5584. [CrossRef]

167. Ketike, T.; Velpula, V.R.K.; Madduluri, V.R.; Kamaraju, S.R.R.; Burri, D.R. Carbonylative Suzuki-Miyaura Cross-Coupling Over Pd NPs / Rice-Husk Carbon-Silica Solid Catalyst: Effect of 1,4-Dioxane Solvent. ChemistrySelect 2018, 3, 7164-7169. [CrossRef]

168. Pourjavadi, A.; Habibi, Z. Palladium nanoparticle-decorated magnetic pomegranate peel-derived porous carbon nanocomposite as an excellent catalyst for Suzuki-Miyaura and Sonogashira cross-coupling reactions. Appl. Organomet. Chem. 2018, 32, e4480 [CrossRef]

169. Peter, C.; Derible, A.; Becht, J.M.; Kiener, J.; le Drian, C.; Parmentier, J.; Fierro, V.; Girleanu, M.; Ersen, O. Biosourced mesoporous carbon with embedded palladium nanoparticles by a one pot soft-template synthesis: Application to Suzuki reactions. J. Mater. Chem. A 2015, 3, 12297-12306. [CrossRef]

170. Gholinejad, M.; Zareh, F.; Nájera, C. Nitro group reduction and Suzuki reaction catalysed by palladium supported on magnetic nanoparticles modified with carbon quantum dots generated from glycerol and urea. Appl. Organomet. Chem. 2018, 32, e3984. [CrossRef]

171. Gholinejad, M.; Najera, C.; Hamed, F.; Seyedhamzeh, M.; Bahrami, M.; Kompany-Zareh, M. Green synthesis of carbon quantum dots from vanillin for modification of magnetite nanoparticles and formation of palladium nanoparticles: Efficient catalyst for Suzuki reaction. Tetrahedron 2017, 73, 5585-5592. [CrossRef]

172. Gholinejad, M.; Seyedhamzeh, M.; Razeghi, M.; Najera, C.; Kompany-Zareh, M. Iron oxide nanoparticles modified with carbon quantum nanodots for the stabilization of palladium nanoparticles: An efficient catalyst for the Suzuki reaction in aqueous media under mild conditions. Chem CatChem 2016, 8, 441-447. [CrossRef]

173. Zhang, Q.; Mao, Z.; Wang, K.; Phan, N.T.S.; Zhang, F. Microwave-assisted aqueous carbon-carbon cross-coupling reactions of aryl chlorides catalysed by reduced graphene oxide supported palladium nanoparticles. Green Chem. 2020, 22, 3239-3247. [CrossRef]

174. Lim, S.Y.; Shen, W.; Gao, Z. Carbon quantum dots and their applications. Chem. Soc. Rev. 2015, 44, 362-381. [CrossRef]

175. Favier, I.; Pla, D.; Gómez, M. Palladium Nanoparticles in Polyols: Synthesis, Catalytic Couplings, and Hydrogenations. Chem. Rev. 2020, 120, 1146-1183. [CrossRef]

176. Leal-Duaso, A.; Mayoral, J.A.; Pires, E. Steps Forward toward the Substitution of Conventional Solvents in the Heck-Mizoroki Coupling Reaction: Glycerol-Derived Ethers and Deep Eutectic Solvents as Reaction Media. ACS Sust. Chem. Eng. 2020, 8 , 13076-13084. [CrossRef]

177. Leal-Duaso, A.; Favier, I.; Pla, D.; Pires, E.; Gómez, M. Design of Glycerol-Based Solvents for the Immobilization of Palladium Nanocatalysts: A Hydrogenation Study. ACS Sust. Chem. Eng. 2021, 9, 6875-6885. [CrossRef]

178. Paul, D.; Rudra, S.; Rahman, P.; Khatua, S.; Pradhan, M.; Chatterjee, P.N. Synthesis and characterization of Pd- $\gamma$-Fe2O3 nanocomposite and its application as a magnetically recyclable catalyst in ligand-free Suzuki-Miyaura reaction in water. $J$. Organomet. Chem. 2018, 871, 96-102. [CrossRef]

179. Liu, X.; Zhao, X.; Zhu, J.; Xu, J. One-pot synthesis of magnetic palladium-NiFe2O4-graphene oxide composite: An efficient and recyclable catalyst for Heck reaction. Appl. Organomet. Chem. 2016, 30, 354-359. [CrossRef]

180. Dasari, G.K.; Sunkara, S.; Gadupudi, P.C.R. One-step synthesis of magnetically recyclable palladium loaded magnesium ferrite nanoparticles: Application in synthesis of anticancer drug PCI-32765. Inorg. Nano-Met. Chem. 2020, 50, 753-763. [CrossRef]

181. Tadjarodi, A.; Dehghani, M.; Imani, M. Green synthesis and characterization of palladium nanoparticles supported on zeolite $Y$ by sonochemical method, powerful and efficient catalyst for Suzuki-Miyaura coupling of aryl halides with phenylboronic acid. Appl. Organomet. Chem. 2018, 32, e4594. [CrossRef]

182. Frias Batista, L.M.; Kunzler, K.; John, M.G.; Clark, B.; Bullock, A.; Ferri, J.; Gupton, B.F.; Tibbetts, K.M. Laser synthesis of uncapped palladium nanocatalysts. Appl. Surf. Sci. 2021, 557, 149811. [CrossRef] 